\title{
Plant-Environment Interactions in the Low Arctic Torngat Mountains of Labrador
}

\author{
Emma Davis, ${ }^{1 *}$ Andrew Trant, ${ }^{1}$ Luise Hermanutz, ${ }^{2}$ Robert G. Way, ${ }^{3}$ \\ Antoni G. Lewkowicz, ${ }^{4}$ Laura Siegwart Collier, ${ }^{2,5}$ Alain Cuerrier, ${ }^{6}$ and \\ Darroch Whitaker
}

\begin{abstract}
${ }^{1}$ School of Environment, Resources and Sustainability, Faculty of Environment, Environment 2 (EV2), University of Waterloo, 200 University Avenue West, Waterloo, Ontario N2L 3G1, Canada; ${ }^{2}$ Department of Biology, Memorial University, St. John's, Newfoundland and Labrador A1B 3X9, Canada; ${ }^{3}$ Northern Environmental Geoscience Laboratory, Department of Geography and Planning, Queen's University, Kingston, Ontario, Canada; ${ }^{4}$ Department of Geography, Environment and Geomatics, University of Ottawa, Ottawa, Ontario, Canada; ${ }^{5}$ Terra Nova National Park, Glovertown, Newfoundland and Labrador AoG 2L0, Canada; ${ }^{6} J a r d i n ~ B o t a n i q u e$ de Montréal, Institut de Recherche en Biologie Végétale, Université de Montréal, 4101, rue Sherbrooke Est, Montreal, Quebec H1X 2B2, Canada; ${ }^{7}$ Western Newfoundland and Labrador Field Unit, Parks Canada, Rocky Harbour, Newfoundland and Labrador A0K 4No, Canada
\end{abstract}

\begin{abstract}
The eastern Canadian Subarctic and Arctic are experiencing significant environmental change with widespread implications for the people, plants, and animals living there. In this study, we integrate
\end{abstract}

Received 29 June 2020; accepted 14 September 2020;

published online 4 November 2020

Electronic supplementary material: The online version of this article (https://doi.org/10.1007/s10021-020-00577-6) contains supplementary material, which is available to authorized users.

Authors Contributions ED led the writing of the manuscript, compiled, and analysed the data. AT contributed to drafting of the manuscript, data collection, and was co-PI for grants supporting vegetation field research activities in Torgnat Mountains National Park, including activities at Nakvak Brook. LH contributed to drafting of the manuscript, established, and maintained the original ITEX warming experimental plots at Nakvak Brook since 2007 with IPY, Weston Foundation, and ArcticNet funding, and collected data on vegetation and soil temperature. RW contributed to drafting of the manuscript, generation of climate data, collection, and analysis of field data. RW was also the PI or co-PI for grants supporting permafrost field research activities in the Torngat Mountains including activities at Nakvak Brook. AL contributed to drafting of the manuscript and led ERT data collection in the field. AL was co-PI for grants supporting permafrost research in the Torngat Mountains including at Nakvak Brook. LSC collected micro-environmental data and managed the vegetation monitoring dataset for the Nakvak Brook site from 2009 to 2016 and reviewed the manuscript. AC collected data and reviewed the manuscript. DW contributed to field logistics and operations, plot maintenance, data collection, and reviewed the manuscript.

*Corresponding author; e-mail: emma.davis@uwaterloo.ca
10 years of research at the Nakvak Brook watershed in Torngat Mountains National Park of Canada, northern Labrador, to assess the sensitivity of ecological and geomorphological systems to regional climate warming. A time series of the Normalized Difference Vegetation Index indicates that the area has undergone a significant greening trend over the past four decades. Analyses of shrub cross sections suggest that greening has been caused by a combination of rapid establishment and growth that began in the late 1990's and coincided with warmer growing season temperatures. Recent (2010-2015) vegetation change has been subtle and heavily moderated by soil moisture status. Plant canopy height is greater in wet areas and has an insulating effect on ground surface temperatures during the winter, a consequence of snow trapping by shrub canopies. Observations of subsurface conditions indicate that the study site is best characterized as having discontinuous near-surface permafrost. The importance of subsurface conditions for above-ground vegetation depends on the geomorphological context, with plants in wet areas underlain by fine materials being the most likely to be growth-limited by permafrost, thus being potential hot-spots for future change. With the 
expectation of sustained climate change, loss of adjacent sea ice, and proximity to the forest-tundra ecotone, it is likely that the Torngat Mountains will continue to be an area of rapid environmental change in the coming decades.

Key words: Shrubification; Permafrost; Climate change; Environmental change; Dendroecology; NDVI; Remote sensing.

\section{HighLights}

- Rapid shrubification has occurred in the Torngat Mountains, Nunatsiavut, Canada

- Field observations indicate the area is characterized by widespread but discontinuous permafrost

- Local differences in plant size and cover are moderated by the soil moisture regime

\section{INTRODUCTION}

Rapid changes have occurred in the distribution (Tape and others 2006; Myers-Smith and Hik 2017) and abundance (Sturm and others 2001b; Elmendorf and others 2012b) of Arctic shrubs in recent decades as climatic limitations on their establishment, growth, and productivity have eased. Large areas of tundra have recently undergone a greening trend (Ju and Masek 2016); however, responses to climate change have been heterogeneous across space and time (Elmendorf and others 2012b; Myers-Smith and others 2020) due to the interconnectedness of Arctic vegetation with various biological and environmental feedbacks (Chapin III and others 2005; Sturm 2005; Morrissette-Boileau and others 2018). Arctic plants provide essential resources and habitat for animals, influence biogeochemical cycling, and impact how humans interact with and make use of the land (Post and others 2009; Pearson and others 2013). Thus, understanding how changes in vegetation characteristics manifest across spatial and temporal scales is critical for predicting future impacts of climate change on tundra ecosystems and the people who use them.

Of the plants that grow beyond the forest-tundra ecotone, shrubs disproportionately influence local environments because of their relatively large physical presence compared to other, low-statured lifeforms. Changes in the size, distribution, and density of shrub species, termed 'shrubification', have been widely observed throughout the Arctic using repeat photography (Tape and others 2006; Lantz and others 2013; Ropars and others 2015b), field experiments (Ackerman and others 2017; Myers-Smith and Hik 2017), and satellite remote sensing (Fraser and others 2011; McManus and others 2012). Shrubs are able to respond quickly to improved conditions through vegetative reproduction and growth (Chapin III and others 1995; Zamin and Grogan 2012), and are often associated with declines in moss and lichen species through shading and litter production (Chapin III and others 1995; Cornelissen and others 2001; Joly and others 2009; Chagnon and Boudreau 2019). Such changes in plant community dynamics have cascading implications for local animal populations; for instance, shrubification may provide new habitat for bird species (Mizel and others 2016; Whitaker 2017), but may be detrimental for caribou which primarily forage for lichen in the winter (Joly and others 2009; Schmelzer and others 2020). Caribou in particular can have a dynamic influence on shrub establishment and growth (Andruko and others 2020) as browsing pressure is linked to overall herd size.

Changes in shrub cover and height also indirectly influence tundra landscapes through various feedback mechanisms, the most impactful of which may be the connection between shrubs and snow redistribution. Upright shrubs trap blowing snow in their dense network of branches, altering local snow accumulation (Pomeroy and others 1997; Sturm and others 2001a) and insulating the ground throughout the winter (Myers-Smith and Hik 2013; Roy-Léveillée and others 2014; Domine and others 2016; Paradis and others 2016). It is hypothesized that winter insulated soils could further amplify shrub growth through elevated rates of organic matter decomposition (Sturm and others 2005), as plants in tundra environments are often nutrient-limited (Weintraub and Schimel 2005). Changes to soil temperatures also affect and are affected by, near-surface permafrost. At local scales, thawing permafrost may enhance shrub establishment by exposing mineral soil (Lantz and others 2009; Frost and others 2013) and altering soil moisture regimes (Osterkamp and others 2009). At regional scales, increasing quantities of terrestrial carbon from peatland and tundra soils are expected to be released due to permafrost thaw in the coming decades (MacDougall and Knutti 2016; Turetsky and others 2020). It has been suggested that the enhanced shading of taller shrubs during the summer could have a cooling influence on permafrost (Blok and others 2010); however, studies 
have shown the magnitude of this effect varies (for example, Johansson and others 2013; Myers-Smith and Hik 2013; Paradis and others 2016) and is generally overwhelmed by the larger magnitude of winter warming through enhanced snow cover (Zhang 2005; Lawrence and Swenson 2011; Loranty and others 2011, 2018; Domine and others 2016).

It is clear that multiple biotic and abiotic processes and feedback loops drive vegetation change in northern environments (Myers-Smith and others 2011,2020$)$. However, much of our knowledge is based on research from western North American Arctic and alpine tundra ecosystems. The eastern Arctic in North America has a stronger maritime climate, was more recently deglaciated (Dyke 2004), began warming later than north-western Canada (Turner and others 2007), and is strongly influenced by the effects of sea ice cover (Banfield and Jacobs 1998). These climatic differences raise the possibility that the direction, rate, or strength of interactions between plants and their environment may also differ. Remote-sensing data show that the eastern Canadian Arctic and Subarctic have recently undergone some of the highest rates of vegetation greening in North America (Fraser and others 2011; Ju and Masek 2016), but there are few in situ studies demonstrating this trend, with most of these studies from lowland sites in Nunavik and eastern Québec (for example, Tremblay and others 2012; Provencher-Nolet and others 2014; Ropars and others 2015a; Paradis and others 2016; Morrissette-Boileau and others 2018). The Torngat Mountains in northern Labrador comprise the southern limit of both the Canadian Arctic and the Arctic Cordillera (Ponomarenko and McLennan 2010; Riley and others 2013), and represent a critical threshold between Subarctic and Arctic ecosystems. Recent climate change in northern Labrador has affected wildlife (Whitaker 2017), glaciers (Way and others 2015; Barrand and others 2017), and terrestrial ecosystems (Siegwart Collier 2020). In the northern Nunatsiavut region of Labrador, sea ice has declined by $33 \%$ per decade from 1981 to 2010 (Barrette and others 2020), locally amplifying the influence of global climate warming. Inuit in Nunatsiavut and Nunavik have observed notable changes in the biophysical environment, including weather, snow, and ice conditions (Downing and Cuerrier 2011; Rapinski and others 2018) and in plant communities (Parks Canada 2008; Cuerrier and others 2015; Siegwart Collier 2020). These many environmental changes have impacts on the health, well-being, and sense of place of Inuit in Labrador (Cunsolo Willox and others 2012). The Torngat Mountains are expected to undergo considerable ecosystem modification over the next century due to changes in the region's climate (Barrette and others 2020) and proximity to the forest-tundra ecotone. An integrated understanding of relationships between vegetation change and the broader environment in the Torngat Mountains remains elusive due to difficulty in accessing this remote and isolated mountain range, and the interdisciplinary methods required to study regional environmental change.

Here, we present the results of ten years of multidisciplinary research on vegetation-environment interactions within the Nakvak Brook watershed in Torngat Mountains National Park of Canada (TMNP; Tongait KakKasuangita SilakKijapvinga in Inuktitut). The area is an Inuit homeland that falls within an overlapping area between the Labrador (that is, Nunatsiavut) and Nunavik Inuit Land Claims Agreements, and the park is cooperatively managed with Inuit from Nunatsiavut and Nunavik. The study was motivated by questions regarding ecosystem change raised during more than a decade of discussions with the Torngat Mountains National Park Cooperative Management Board, as well as time spent sharing observations on the land with Inuit [including Park staff, members of the Cooperative Management Board, local Inuit students, professional bear guards, and a co-author who is of Inuit descent (R.G. Way)]. We combine long-term remote-sensing data with fieldbased observations of vegetation change and permafrost to characterize the climatic and biophysical environment, and to assess the sensitivity of ecological and geomorphological systems to ongoing climate change. Combining field observations with time series data allows us to contextualize local conditions within a recent history of regional environmental change in a remote, topographically complex, marine-influenced mountain range, and offers insight into how further changes might manifest in the future.

\section{Study Location}

The study area at Nakvak Brook (Pitukkik in Inuktitut) is situated in a coastal Cordilleran landscape at the transition between the Canadian low Arctic and Subarctic regions in northern Labrador $\left(58.64^{\circ} \mathrm{N}, 63.35^{\circ} \mathrm{W} ; 420 \mathrm{~m}\right.$ above sea level (asl); Figure 1). The nearby Nakvak Brook valley leads to the Koroc River valley, Québec, and has been used by Inuit as a travel route between the Labrador coast and Ungava Bay for generations. Atmospheric reanalysis data (ERA5; Hersbach and others 2020), 


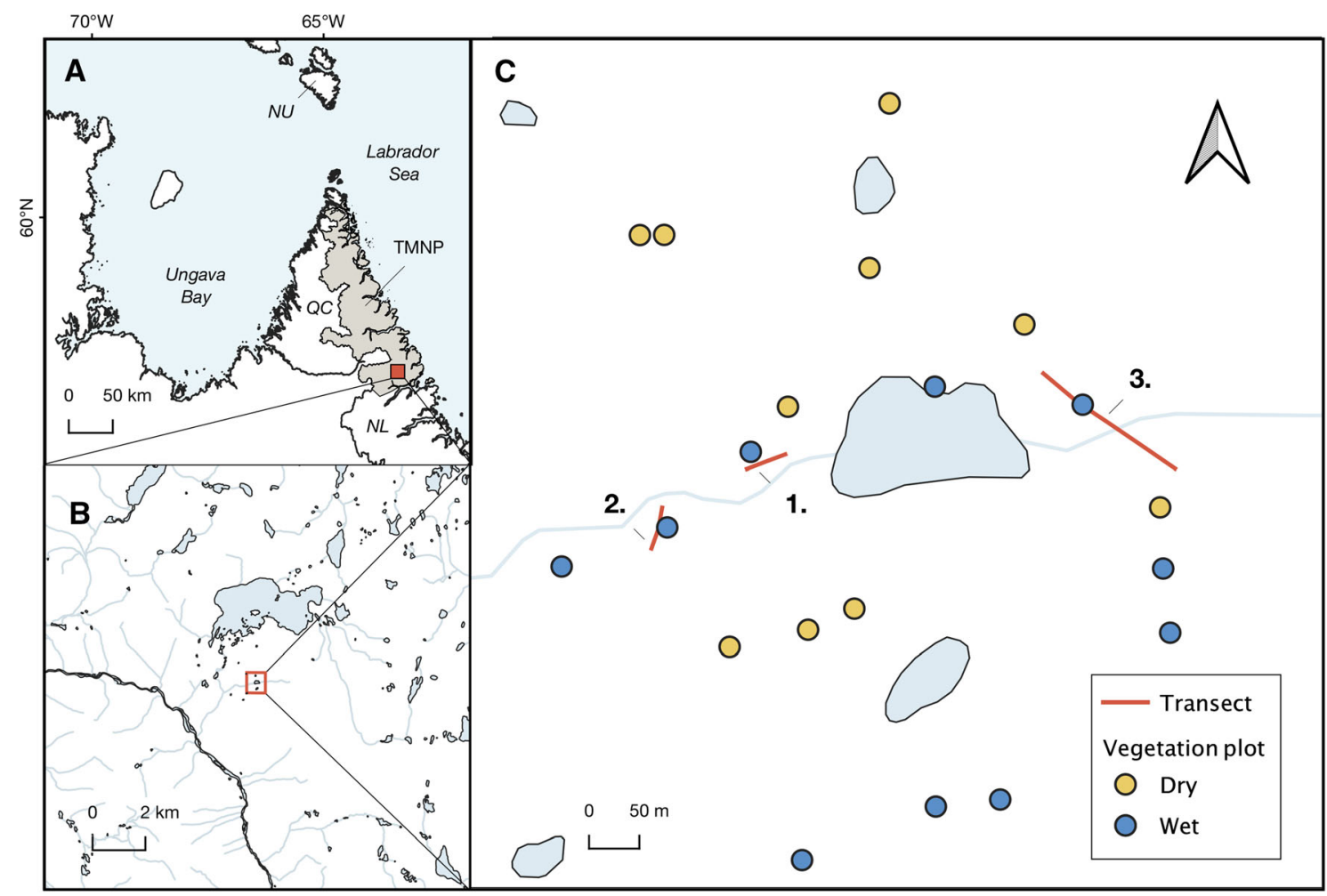

Projection: WGS84 UTM 20N

Figure 1. A Map of the study region in Torngat Mountains National Park (TMNP), northern Labrador. The red square indicates the study area at Nakvak Brook. B Spatial extent of the NDVI imagery used in this study; the red box indicates the extent of plot-scale measurements. C Schematic of the study site showing locations of vegetation plots, three permafrost electrical resistivity tomography/shrub transects, and water features.

statistically downscaled to the location and elevation of the site, indicate that mean temperatures of the coldest and warmest months are $-25{ }^{\circ} \mathrm{C}(\mathrm{Fe}-$ bruary) and $8{ }^{\circ} \mathrm{C}$ (August), respectively, and that the area experiences a mean annual precipitation of $875 \mathrm{~mm}$, much of which accumulates as snow from October to May (1989-2018 climate normals). The regional climate is influenced by the Labrador Current, which promotes cold maritime conditions during the summer growing season and delays peak summer warmth to August, and by seasonal sea ice cover, which causes the climate in the region to become increasingly continental during winter (Banfield and Jacobs 1998).

Geomorphologically, the Nakvak Brook research site is a relatively flat upland basin surrounding a shallow lake, with relief to the east that rises to $900 \mathrm{~m}$ asl. The study site is located about $25 \mathrm{~km}$ inland from the coast of the Labrador Sea and ca. $15 \mathrm{~km}$ from the outflow of Nakvak Brook in Saglek Fiord. Local high points have relatively minimal (inferred as $<1 \mathrm{~m}$ thick) surficial cover, whereas riparian deposits are thicker $(>3 \mathrm{~m})$ and range from coarse to medium in particle size. The finest soils exist at the lowest elevations next to streams entering and leaving the largest central lake (Figure 1C). Soil moisture is highly variable within the study site with a network of small surface runoff channels and alternating areas of saturated and dry ground. Visual observations (L. Hermanutz) suggest that wet areas have undergone a drying trend in the last decade, supported by limited soil moisture measurements at the site (Supplementary Figure 1). According to the Permafrost Map of Canada (Heginbottom and others 1995), the region is underlain by extensive discontinuous to continuous permafrost; however, recent studies classify the broader region as extensive discontinuous permafrost (Way and Lewkowicz 2016; Obu and others 2019).

Ground cover at Nakvak Brook is primarily composed of low tundra vegetation and exposed rock. Arctic dwarf birch (Betula glandulosa Michx. (AvâlaKiak in Inuktitut)), willow (Salix herbacea L.; S. arctica Pall (UKaujak); Salix spp.), and blueberry (Vaccinium uliginosum L. (Kigutanginnak)) are the 
dominant deciduous shrub species in the area. Dry areas tend to have a greater abundance of lichen and evergreen shrubs, whereas mosses and graminoids are more common in wet areas. The larger TMNP region, including the Nakvak Brook watershed, has experienced a dramatic increase in vegetation and decrease in bare ground over the past several decades, including rapid expansion of tall shrubs in valley bottoms (Fraser and others 2011; Quirouette and Zorn 2015; Ju and Masek 2016). At the same time, there has been a significant decline in number of caribou in the Torngat Mountains since the 1990s, in large part due to the collapse of the migratory George River population, which used to range into the region, and possibly also due to a decline in the locally resident, but much smaller, Torngat Mountains population (Couturier and others 2015; COSEWIC 2017). The size of the Torngat Mountains population has recently increased slightly (ca. to 1300 individuals in 2017), but numbers remain low and the range of the remnant George River population no longer includes this region (Couturier and others 2018). Thus, it can be presumed that caribou browsing pressure has declined during the past 20 years.

\section{MethoDS}

\section{Low Altitude Imagery From Remotely Piloted Aircraft}

Low altitude remotely piloted aircraft (RPA) (DJI Phantom 4 Pro quadcopter) imagery $(N=1068)$ was acquired at Nakvak Brook on 4 August 2018 and was used to characterize the local geomorphological context and spatial distribution of surface features (large vegetation patches, streams, lakes, frost sorted features) in relation to field data. RPA imagery and a description of collection and processing methods are provided in Supplementary Figure 2.

\section{Decadal-Scale Changes in Air Temperature and Vegetation}

Climate and surface reflectance data were acquired to generate local records of temperature and vegetation change for the study area. Prior research in Labrador has shown that scaling atmospheric reanalysis and gridded climate products can improve local temperature estimates in the absence of long-term meteorological stations (Jacobs and others 2014; Finnis and Bell 2015; Way and Bonnaventure 2015; Way and Viau 2015; Way and others 2017). Daily mean surface air temperatures
(SATs) from ERA5 atmospheric reanalysis (Hersbach and others 2020) were extracted using Google Earth Engine (Gorelick and others 2017) for grid cells $\left(0.25^{\circ}\right)$ covering most of TMNP and adjacent areas (January 1979-August 2019). ERA5-derived SATs were then locally scaled with linear regression using short records of SAT from ecosystem monitoring stations operated by Parks Canada and Centre d'études nordiques (Sarrazin and Allard 2020) in northern Labrador and Nunavik ( $N=15$; mean coverage of 5.7 years per station since 2010). Daily SATs for Nakvak Brook (427 m asl) were then calculated from the locally scaled ERA5 estimates using thin-plate spline interpolation within the 'fields' package (Nychka and others 2017) in R (R Core Team 2020), employing positional coordinates and elevation as predictors (as in Way and others 2017).

Time series of the Normalized Difference Vegetation Index (NDVI) derived from remote-sensing imagery are commonly used as a proxy of decadalscale changes in vegetation productivity. In highlatitude environments, NDVI is related to aboveground phytomass (Raynolds and others 2012) with shrubs generally having higher NDVI values due to their greater canopy leaf area relative to other tundra plants (Boelman and others 2011). Landsat imagery $(5,7$, and $8 ; 30 \mathrm{~m}$ resolution) was used to develop an NDVI time series for a $250 \mathrm{~km}^{2}$ area around the study site at Nakvak Brook (Figure 1B). A quality control procedure developed by Pironkova and others (2018) automated the acquisition of cloud-free, sensor-calibrated images in Google Earth Engine from which annual median July-August NDVI values were calculated. Due to persistent cloud cover in some years, site-level median NDVI values are available for only 23 of 34 years. Estimates of monotonic rates of change over 1985-2019 were calculated using Theil-Sen's slope estimator in the 'EcoGenetics' package (Roser and others 2017) in R. The distributions of NDVI values between averages of the first (1985-1994) and most recent (2010-2019) 10 years of observation were compared using a Kolmogorov-Smirnov test. Together, the local temperature and NDVI time series provide a decadal-scale record of environmental change that contextualizes recent fieldbased observations.

\section{Plot-Scale Changes in Plant Growth and Composition}

A series of vegetation surveys were undertaken to connect regional-scale changes with observations at the local level. Surveys of shrub composition 
were performed along three transects at Nakvak Brook in the summer of 2017 (see site and transect layout in Figure 1C). Shrub ramets were collected from a representative sample of individuals in each transect $(n=4-12)$ to develop establishment and growth records. Care was taken to ensure that ramets were collected from unique plants because many arctic shrubs reproduce vegetatively through the production of rhizomes. The largest, and presumed oldest, shrub ramet was cut at the root collar, and the basal cross sections were used to estimate the minimum year of establishment and to develop an annually resolved ring-width chronology. Samples from Transect 1 were also serially sectioned at $10-\mathrm{cm}$ intervals along the remainder of the stem to calculate rates of stem elongation.

Ramet cross sections were prepared, dated, and analysed using standard dendrochronological methods adapted for shrub species (Myers-Smith and others 2015; see Supplemental Material 1). Recent increases in shrub size were determined from ramet subsections (Figure 1C; Transect 1) by examining changes in the rates of stem elongation over time. Stem elongation data were used to fit linear and negative exponential models with the position of the sample along the ramet $(\mathrm{cm}$ from base) as the dependent variable and the year in which it reached that length as the independent variable. A value of $0.1 \mathrm{~cm}$ was added to stem lengths in the exponential model to permit the inclusion of the initial $0 \mathrm{~cm}$ class in the model. The model with the highest explained variance (greatest $R^{2}$ ) was considered to have the best fit, with a linear model implying a constant rate of stem elongation over time and a negative exponential implying an increasing rate. Finally, an annual radial growth chronology was established for the study area using the growth measurements of the basal samples of $B$. glandulosa, the most common shrub species in the transects. The chronology was developed from an initial 18 individuals by detrending cross-dated ring-width series using the series mean, as no age-related growth trends were apparent (Myers-Smith and others 2015). Detrended series were combined using Tukey's biweight robust mean, and autoregressive prewhitening was applied to account for non-independence between subsequent years of shrub growth (Cook and others 1990). Spearman rank correlations were performed (due to limited years of observation) between the residual $B$. glandulosa growth chronology (1998-2017; 20 years) and three temperature records (mean July, August, and July-August temperatures); between July-August NDVI and the growth chronology (1998-2017;
14 years due to missing years of NDVI data); and between NDVI and the temperature records (19852017; 23 years due to missing years of NDVI data).

Point-frame vegetation surveys were conducted during the 2010 and 2015 growing seasons to identify short-term temporal changes in plant composition and abundance at Nakvak Brook under ambient climate conditions. Methods developed for the International Tundra Experiment (ITEX; https://ibis.geog.ubc.ca/itex/) were used to collect information about plant cover, size, and abundance in permanent sample plots. To account for the moderating effect of soil moisture on plant responses to climate warming (Elmendorf and others 2012b; Ackerman and others 2017; Bjorkman and others 2018), a representative sample of 10 'wet' and 10 'dry' plots were established in $2007 / 2008$. Wet plots were qualitatively distinguished as having saturated soil and/or some standing water, whereas dry plots had no standing water and had dry soils. Instantaneous soil moisture recordings were made during field visits in July or August of 2009, 2010, 2011, and 2013 using a type wet-2 WET Sensor and HH2 Moisture Meter (Delta-T Devices Ltd) (Supplementary Figure 1). The plots measured $1 \mathrm{~m} \times 1 \mathrm{~m}$ and the pointframe had a grid spacing of $10 \mathrm{~cm}$, resulting in 100 points for vegetation data collection per plot. During the surveys, each encounter between a plant and a point-frame pin, and the height at which it occurred, was recorded. Plants were identified to the species level when possible; however, some could only be identified to genus. Plants were grouped as deciduous shrub, evergreen shrub, forb, graminoid, lichen, or moss for statistical analyses. Bare ground was categorized as rock, exposed soil, or cryptogamic crust, and standing dead plants or litter were grouped as dead organic material.

Linear mixed-effect (LME) and generalized linear mixed models (GLMM; 'Ime4' package; Bates and others 2015) were used to evaluate changes in bare ground, plot canopy height, maximum plant height, living plant abundance, and abundance of dead plant material across years and between plot moisture status (see Supplemental Material 2). LME models were used to fit maximum plant (one model per lifeform) and mean canopy height data, and GLMMs were used for bare ground cover (binomial distribution), life-form abundance (one model per lifeform; Poisson distribution with loglink), and dead plant material data (Poisson distribution with log-link). In all models, soil moisture class (wet versus dry), survey year (2010 versus 2015), and their interaction were the fixed effects, 
and a categorical variable for plot ID was the random term.

Ground surface temperatures (GST) were monitored at the corners of vegetation plots from 2010 to 2019 using HOBO $^{(\mathrm{R})}$ Onset UA-001-08 pendant temperature loggers to infer changes in local surface conditions over the observational period and between wet and dry plots. The temperature loggers were buried between 2 and $5 \mathrm{~cm}$ below the soil surface and recorded temperatures at 1-h or 2$\mathrm{h}$ intervals, depending on the year. Ground surface data were interpolated to an hourly interval (maximum gap of $3 \mathrm{~h}$ ) using a cubic spline to correct for time of observation bias and were then aggregated to daily mean values. Ground surface temperature data were analysed using the temperature at the top of the permafrost model framework (Smith and Riseborough 1996; Riseborough 2004) following Way and Lewkowicz (2018). Interannual differences between warm season air (local ERA5 estimates) and soil (observed) temperatures were summarized using the thawing season offset (TSO; for example, Way and Lewkowicz 2018), whereas differences between cold season air (estimated) and soil (observed) temperatures used the nival offset (NVO; for example, Riseborough 2004; Way and Lewkowicz 2018 see Supplementary Material 3). Using TSO and $\mathrm{NVO}$ is preferred to more commonly used metrics (for example, $n$-factors) because it enables direct comparisons of net air-surface temperature differences during warm and cold seasons, respectively. Statistical differences in TSO and NVO between wet and dry plots were determined for 2012-2018 (years with sufficient data coverage) using linear mixed-effects models; soil moisture class, year, and their interaction were fixed effects, and plot ID was the random term. A Spearman correlation was performed to determine if relationships existed between average annual NVO, TSO, and the average height of the plot canopy.

\section{Permafrost Investigation}

Permafrost characteristics at Nakvak Brook were investigated in late July 2017 using DC electrical resistivity tomography (ERT) and standard field methods including frost probing, instantaneous temperature profiling, and ground temperature observations (Lewkowicz and others 2011). ERT can be used to infer the presence or absence of frozen soil or rock by modelling the pattern of measured resistance to electrical current between pairs of electrodes inserted in the ground (Hauck and others 2003; Hauck 2013). Frozen ground is generally more resistive to current than unfrozen materials due to lower unfrozen moisture contents (Hauck 2013), but dry unfrozen soils and bedrock can exhibit resistivities that overlap with the range observed for frozen soils. Given the relatively coarse soils and near-surface bedrock present at Nakvak Brook, validation in relation to frozen ground conditions proved challenging.

ERT investigations were conducted along three transects that sampled a variety of local conditions (Figure 1C) and were co-located with shrub surveys. Resistivities were measured with an ABEM Terrameter LS profiling system using a Wenner configuration across $40 \mathrm{~m} \quad(N=2)$ and $160 \mathrm{~m}$ $(N=1)$ transects (maximum depth penetration of $7 \mathrm{~m}$ and $26 \mathrm{~m}$, respectively). RES2DINV was used to invert measured resistivities with the robust inversion method (Loke and Barker 1996, 2003) and was subsequently exported to $x-y-z$ data after errors dropped below 5\% and/or error values fell by $<1 \%$ between model fit iterations (for example, Way and others 2018). Profiles were topographically corrected using elevations collected in the field with a handheld GPS (Garmin Oregon 450t) and a Brunton compass. ERT tomograms are presented as model blocks with larger blocks at depth and near the ends of profiles. Tomograms were generated using a customized R v3.4 script, and areas below the depth of investigation from RES2DINV (per Loke and others 2003) were excluded. For validation, we used instantaneous ground temperature profiles collected with Onset Hobo UX120-006M Analog Data Loggers (accuracy $\pm 0.15^{\circ} \mathrm{C}$ ) connected to two to four vertically arranged thermistors separated by $20 \mathrm{~cm}$ and mounted on a wooden dowel (for example, Way and Lewkowicz 2015; Holloway and Lewkowicz 2020). The observed thermal gradient in the lower $20 \mathrm{~cm}$ was used to extrapolate temperatures to $0{ }^{\circ} \mathrm{C}$ in order to approximate the thaw depth. This likely underestimates the active layer thickness because measurements were made before the end of the thaw season.

To further elucidate permafrost conditions at Nakvak Brook, 1000 simulations of permafrost probability were run using the equilibrium temperature at the top of the permafrost model (Smith and Riseborough 1996) for 14 vegetation plots that had longer records of ground surface temperatures (see Supplementary Material 2 for additional details regarding permafrost simulations). 


\section{RESUlts}

\section{Decadal-Scale Changes in Air Temperature and Vegetation}

Locally scaled ERA5 data showed warming trends at Nakvak Brook in all seasons (Figure 2). Cooling was observed from 1979 to 1990 , followed by rapid warming until 2011 , and then elevated but variable temperatures from 2011 to 2019. Temperature increases in autumn and winter were greater than those in spring and summer.

The median July-August NDVI record derived from Landsat showed a general increase over time. Rates of change in NDVI (Theil-Sen slope estimates; change in NDVI value per year) varied spatially, with the greatest increase occurring along the valley-side slopes of drainage channels now occupied by tall, upright shrubs (south-west portion of Figure 3). Average NDVI values increased from 0.218 to 0.328 between the first (1985-1994) and most recent (2010-2019) ten-year periods of observation, and the Kolmogorov-Smirnov test indicated a significant difference in cumulative distribution functions $(D=0.260 ; p<0.001)$ as values became more positive over time.

\section{Plot-Scale Changes in Vegetation Growth and Composition}

Shrubs growing in the survey transects were primarily dwarf birch (B. glandulosa, 18 of 26 individuals), with the remainder being species of willow (Salix pedicellaris, 7 of 26; Salix sp., 1 of 26). Ramet establishment varied between 1997 and 2014 and peaked in 2006 (Supplementary Figure 3a). The oldest shrubs were B. glandulosa and all Salix established after 2005. Shrub establishment tended to be greater in years with higher average July temperatures, although this observation is based on a small number of samples (Supplementary Figure $3 b$ ). Serial sectioning of shrub ramets from Transect 1 revealed that stem elongation increased exponentially over time at the transect-level $\left(R^{2}\right.$ of negative exponential model $=0.64$; $p<0.001$ relative to $R^{2}=0.50 ; p<0.001$ for the linear model; Figure 4). Modelled shrub stem lengths increased rapidly after ca. 2005, with annual growth rates increasing from less than $1.00 \mathrm{~cm} / \mathrm{y}$ in 2005 to $13.25 \mathrm{~cm} / \mathrm{y}$ in 2014 .

The final radial growth chronology contained measurements from 13 dwarf birch ramets and spanned 21 years (1997-2017; Supplementary Figure $3 b)$. Shrub radial growth generally increased and became more variable over time. Although performed on a limited number of data points (1423 years), correlation analyses between shrub growth, NDVI, and summer temperatures show significant, positive relationships (Figure 5). The strongest correlations were with mean August air temperatures, rather than mean July or July-August values $(p>0.05)$. August is typically the warmest month of the growing season at Nakvak Brook, as noted above.

Interestingly, the point-frame vegetation surveys showed plant size and abundance to differ most between moisture categories (wet versus dry plots) as opposed to between survey years (2010 and 2015). Plant canopies were taller in wet than in dry plots $\left(t_{\mathrm{wet}}=4.61 ; p<0.001\right.$; Figure 6; see Supplementary Tables $1-3$ for full model parameter estimates), as were the maximum heights of deciduous shrubs $\left(t_{\mathrm{wet}}=10.70 ; p<0.001\right)$, forbs $\left(t_{\mathrm{wet}}=6.50, p<0.001\right)$, and graminoids $\left(t_{\mathrm{wet}}=\right.$ 8.60; $p<0.001)$. Forbs $\left(z_{\text {wet }}=3.13 ; p<0.001\right)$,
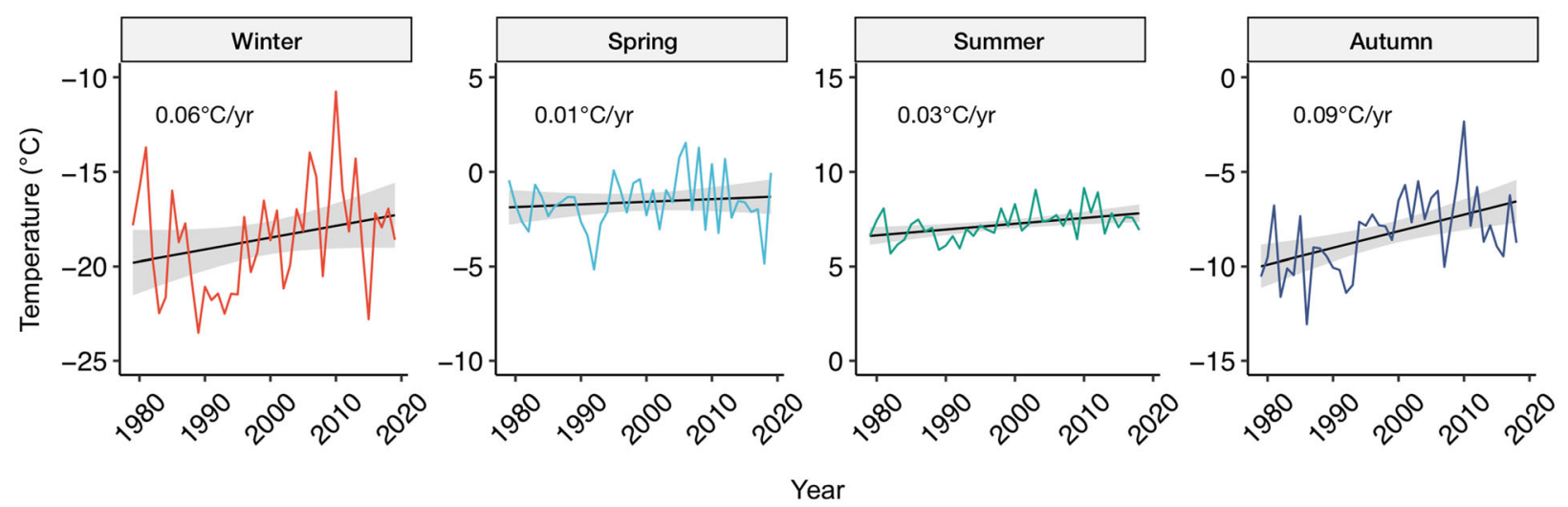

Figure 2. Changes in seasonal average temperatures for Nakvak Brook (1979-2019) derived from locally scaled ERA5 atmospheric reanalysis data. Ordinary least squares regression lines are shown with shaded areas indicating $95 \%$ confidence intervals (note different temperature ranges on $y$-axes). 


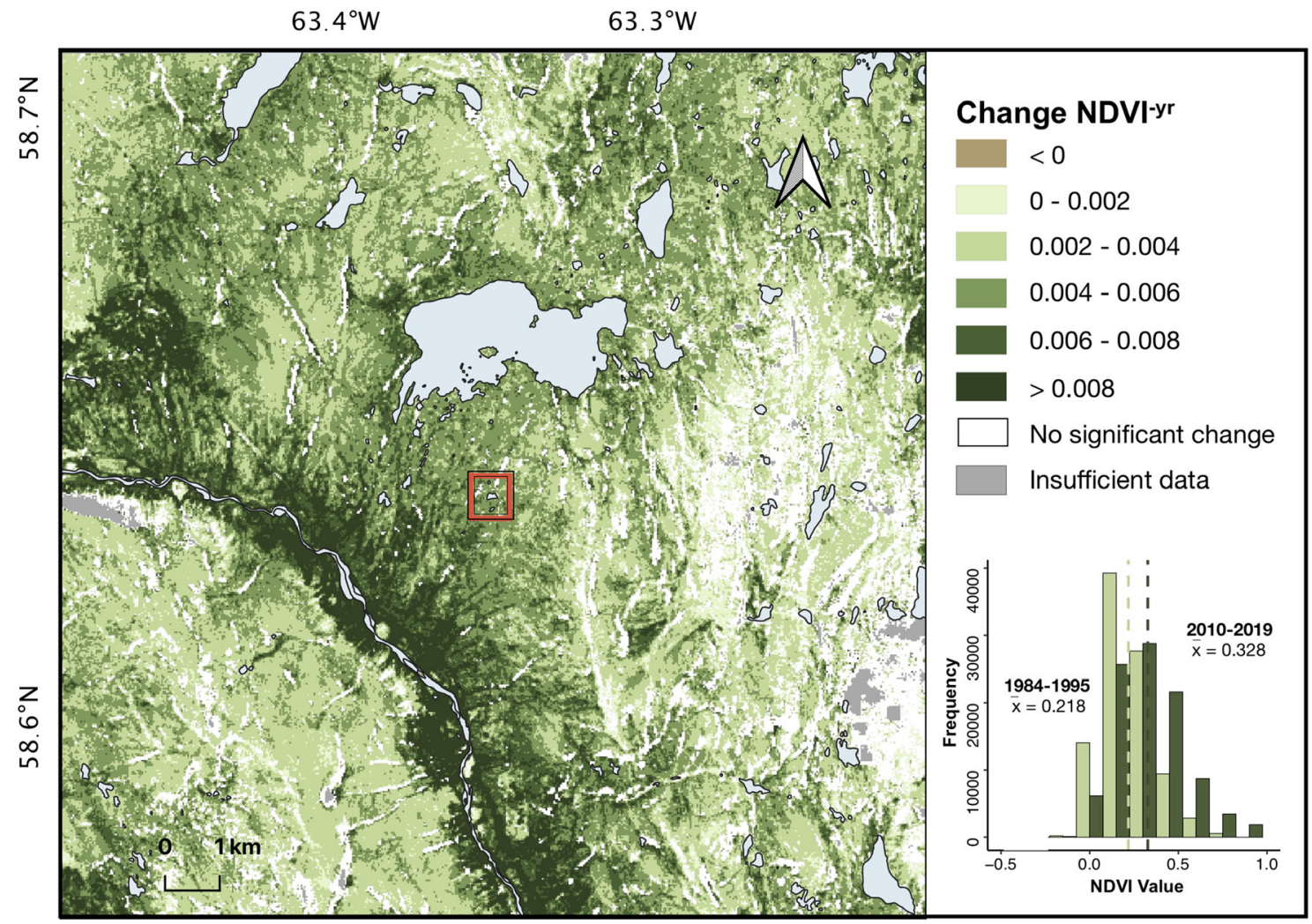

Projection: WGS84 UTM 20N

Figure 3. Observed changes in NDVI from 1985 to 2019 shown for a $250 \mathrm{~km}^{2}$ area around the study site at Nakvak Brook (red box, centre). Rates of change are significant Theil-Sen slope estimates $(a<0.05)$ measured in NDVI units per year. Bottom right: Frequency histogram of the distribution of NDVI values during the first (1985-1994; light green) and most recent (2010-2019; dark green) 10 years of observation, for years in which adequate imagery was available. Dashed coloured lines represent the mean NDVI value of each time period.

graminoids $\left(z_{\text {wet }}=2.00 ; p<0.001\right)$, and moss $\left(z_{\text {wet }}=1.47 ; p<0.001\right)$ were more abundant in wet plots, whereas evergreen shrubs and lichen were favoured in dry plots where they were both taller (evergreen shrubs: $t_{\mathrm{wet}}=-3.20 ; p=0.03$ ) and more abundant (evergreen shrubs: $z_{\text {wet }}=$ $-4.18 ; p<0.001$; lichen: $\left.z_{\text {wet }}=-4.62 ; p<0.001\right)$.

Temporal changes in plot surveys mainly relate to differences in life-form abundance, although the maximum height of graminoids uniquely decreased from 2010 to 2015 regardless of soil moisture status $\left(t_{2015}=-3.10 ; p=0.010\right)$. Forbs increased in abundance in $2015\left(z_{2015}=1.27 ; p=0.003\right)$, and more so in dry than wet plots $\left(z_{\text {wet }^{*} \text { year }}=-1.09\right.$; $p=0.015)$. This change in abundance was driven by an increase in the amount of some species (for example, Polygonum viviparum) as well as the appearance of new species that were not present in the plots in 2010 (for example, Equisetum arvense, Euphrasia arctica; Oxytropus campestris). In contrast, the interaction between plot moisture category and year was significantly positive in the model of graminoid abundance $\left(z_{\text {wet }^{*} \text { year }}=0.43 ; p=0.013\right)$, indicating that the increase was greater in wet plots. Lichen abundance increased very slightly from 2010 to 2015, independent of moisture class $\left(z_{2015}=0.27 ; p=0.001\right)$, and moss declined in wet plots in $2015\left(z_{\text {wet }^{*} \text { year }}=-0.59 ; p<0.001\right)$. The likelihood of encountering standing dead plant or plant litter decreased in 2015 relative to 2010 $\left(z_{\text {year }}=-0.88 ; p<0.001\right)$, and declined more in wet than dry plots $\left(z_{\text {wet }^{*} \text { year }}=0.44 ; p=0.001\right)$. Finally, the GLMM for bare ground cover showed there to be no differences between years $\left(z_{\text {wet }}=\right.$ $0.18 ; p=0.282)$ or between plot status $\left(z_{\text {wet }}=\right.$ $-1.22 ; p=0.170)$. There was no evidence of caribou herbivory within the plots or in the immediate area.

Ground surface temperatures recorded at vegetation plots showed that air-surface temperature differences were larger in the winter (that is, higher NVO) at wet sites than at dry sites (Figure 7; Sup- 
plementary Table 4). Snow cover warmed the ground surface by about $2-6{ }^{\circ} \mathrm{C}$ relative to air temperatures, and the average difference in NVO between wet and dry plots was $1.15{ }^{\circ} \mathrm{C}$ (LME; $\left.p_{\text {wet }}=0.011\right)$. Wet plots showed less variability in NVO than dry plots, indicating greater consistency in the air-surface temperature decoupling in the cold season at wet sites. The correlation analyses showed mean NVO to be positively related to plot canopy height (Rho $=0.68 ; p=0.010)$. Unlike NVO, TSO did not differ significantly between

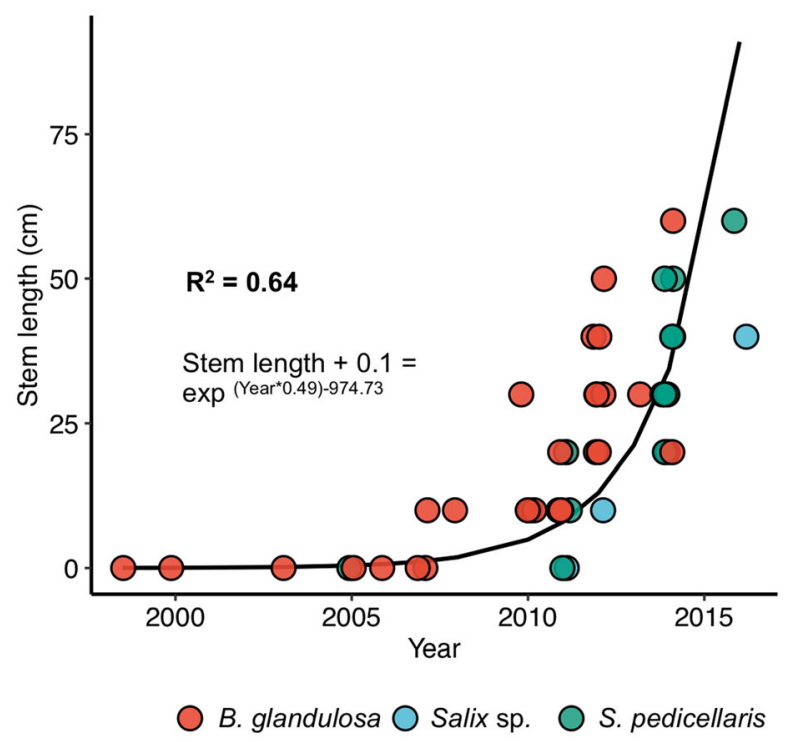

Figure 4. Rate of stem elongation $(\mathrm{cm} / \mathrm{yr})$ for 10 individuals growing in Transect 1 with colours indicating shrub species. Elongation rates were best described by an exponential relationship, indicating that the transect-level growth rate of dominant stems has accelerated over time. A slight jitter in points along the $x$-axis was used to show overlapping data. moisture classes $\left(t_{\mathrm{wet}}=0.04 ; p=0.805\right)$ and its impact on GSTs was smaller, generally between $-0.5^{\circ} \mathrm{C}$ and $+0.5^{\circ} \mathrm{C}$. This indicates that shading by vegetation results in minimal air-surface temperature decoupling in both wet and dry plots, with thawing season air temperatures warmer than the ground surface in some years and colder in others, and with no consistent trend. The relationship between TSO and canopy height was negative but not significant (Rho $=-0.37 ; p=0.200)$. Overall, the influence of NVO on GST, mainly due to snow, was often an order of magnitude larger than the influence of TSO, mainly due to shading by plants and other thawing season impacts (for example, soil moisture). Thus, interannual variability in the yearly offset between air and GST is primarily driven by differences in snow accumulation and redistribution around the study site.

\section{Site-Specific Permafrost Investigations with ERT}

\section{Transect 1}

Transect 1 traversed a very gently sloping section of the valley bottom covered by low herbaceous vegetation with prostrate willows in places. Small $(10-20 \mathrm{~cm})$ rises and falls in the surface corresponded to locally drier and wetter conditions in the fine-grained surficial deposits. Frost-shattered rocks on the surface near the start of the transect suggest that bedrock contact may be quite close to the surface. The tomogram shows a 0.5-1-m-thick layer of mostly low resistivities (minimum: $1075 \Omega \mathrm{m}$; median: $2100 \Omega \mathrm{m}$ ) overlying a body of higher resistivities (minimum: $1840 \Omega$ m; median: $13,700 \Omega \mathrm{m}$ ) that extends to the base of the profile at $7 \mathrm{~m}$ depth (Figure 8A). A clear frost table was
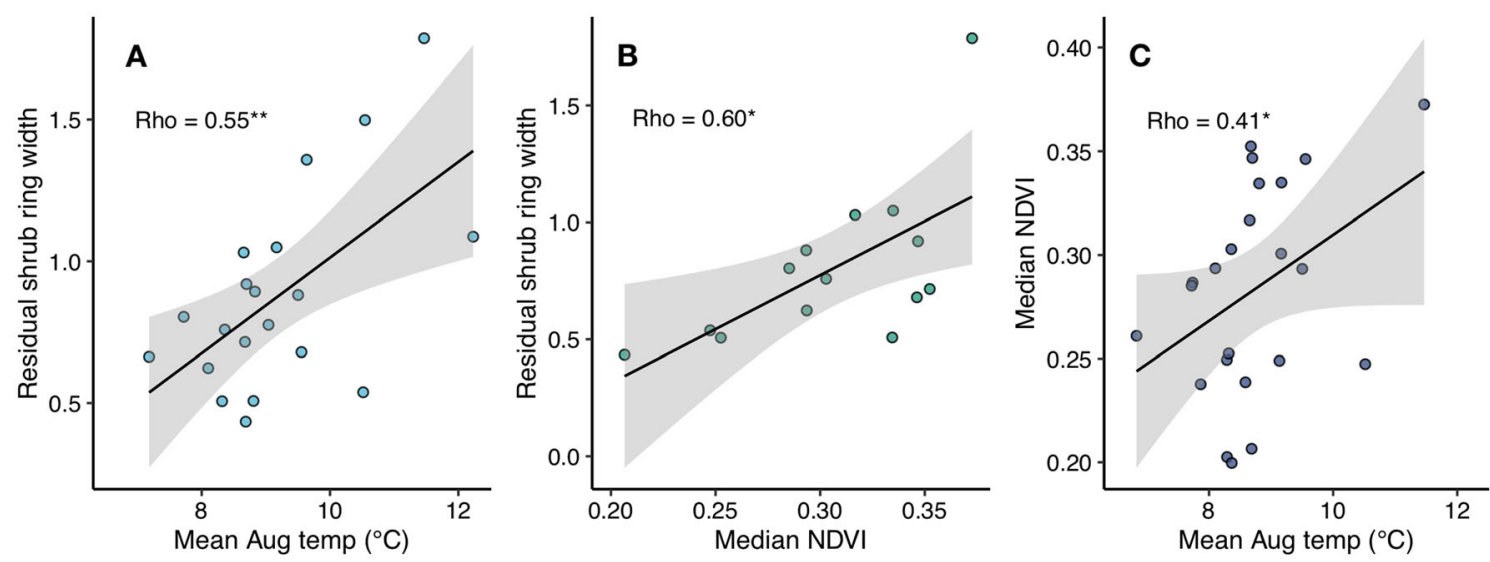

Figure 5. Relationships between: A shrub ring widths and average August temperatures; B shrub ring widths and median July-August NDVI; and C July-August NDVI and August temperatures for the study area $\left({ }^{*} p \leq 0.05 ;{ }^{* *} p \leq 0.01\right)$. 


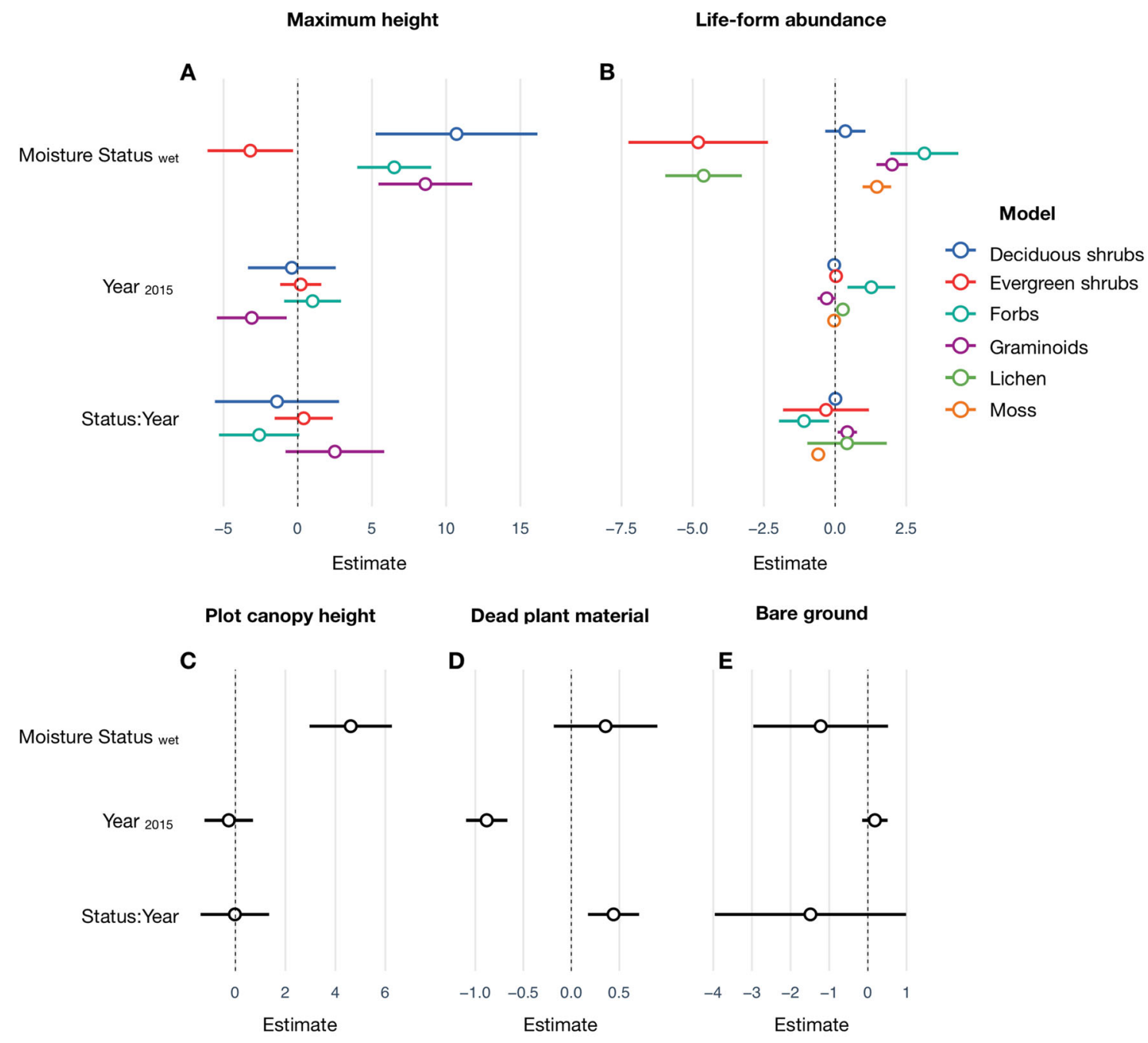

Figure 6. Effects of moisture class, year, and their interaction on: A the maximum height of each life-form; B life-form abundance; $\mathbf{C}$ average height of the plot canopy; D abundance of dead plant material; and $\mathbf{E}$ bare ground cover. Significant effects have $95 \%$ confidence intervals (bars) that do not overlap zero. Dry plots and the 2010 survey are the baseline categories against which the effects are measured.

encountered at depths ranging from 28 to $50 \mathrm{~cm}$ at several locations along the transect during probing in late July. Instantaneous ground temperatures collected at $12 \mathrm{~m}$ and $35 \mathrm{~m}$ along the profile also indicate the presence of frozen ground at depths of $47 \mathrm{~cm}$ and $40 \mathrm{~cm}$. A permafrost mound about $70 \mathrm{~cm}$ high with a thaw depth estimated at $43 \mathrm{~cm}$ was present within $35 \mathrm{~m}$ of the profile. Taken together, the observations at Transect 1 indicate a thin, thawed layer overlying frozen ground, some of which could be bedrock. Given the timing of the survey and the shallow depths of thaw, these are interpreted as representing an active layer of variable thickness overlying permafrost at least $7 \mathrm{~m}$ thick.

\section{Transect 2}

Transect 2 ran across the valley bottom, and in the first $20 \mathrm{~m}$ and last $5 \mathrm{~m}$, it intersected a series of drainage channels. The channels were mostly $<1 \mathrm{~m}$ wide, incised $30-40 \mathrm{~cm}$ relative to the adjacent terrain and lined with angular rocks 15$30 \mathrm{~cm}$ in diameter. Water was present in the channels, and soil in the areas between them was saturated at a depth of $30 \mathrm{~cm}$. Vegetation along the transect was classified as wet sedge. The tomogram shows a two-layered system, with a 2-3-m-thick low resistivity layer (minimum: $112 \Omega$ m; median: $745 \Omega \mathrm{m}$ ) with some higher resistivity patches linked to problems with contact resistance, bounded by a sharp gradient with a higher resistivity body (minimum: $2010 \Omega \mathrm{m}$; median: 18,520 $\Omega \mathrm{m}$ ) 

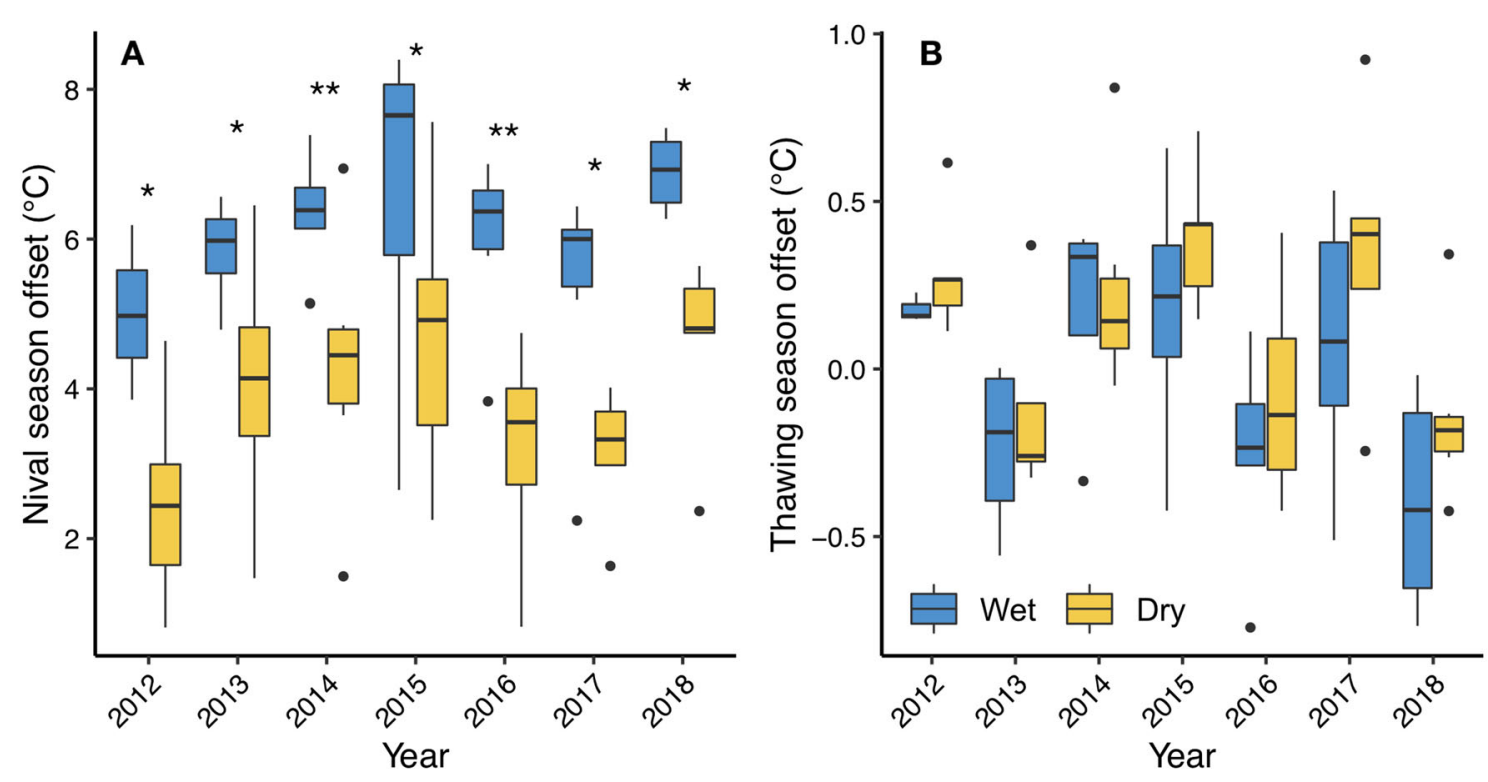

Figure 7. Annual differences in A nival (NVO) and B thawing (TSO) season offset between wet and dry vegetation plots (2012-2018). NVO and TSO values were derived from ground surface temperature loggers and locally scaled air temperatures for Nakvak Brook. Differences between wet and dry plots were determined using Tukey post hoc contrasts $\left({ }^{*} p \leq 0.05 ;{ }^{* *} p \leq 0.01\right)$. Note differences in scale of $y$-axis.

that extends to the base of the profile at $7 \mathrm{~m}$ depth (Figure 8B). Probing for the frost table did not reveal a defined thaw front along this profile, as clasts were encountered at shallow depths in many places. The maximum probe depth reached was $88 \mathrm{~cm}$ at $34 \mathrm{~m}$ along the profile, but refusal was due to a clast rather than frozen ground as the temperature at this depth was $7{ }^{\circ} \mathrm{C}$. Two instantaneous ground temperature measurements gave estimated depths for $0{ }^{\circ} \mathrm{C}$ as $251 \mathrm{~cm}$ and $384 \mathrm{~cm}$. Considering the substrate and drainage conditions at Transect 2, we infer that the low resistivity values in the nearsurface indicate soil thawed to at least a depth of 2$3 \mathrm{~m}$, and saturated conditions. High resistivities at greater depths could either be deep permafrost or bedrock. Even if permafrost is present, the depth of the $0{ }^{\circ} \mathrm{C}$ isotherm attained by mid-summer, as indicated by the tomogram and the ground temperature measurements, shows it is likely that the thawed layer would not completely refreeze in winter, meaning a talik would be present.

\section{Transect 3}

The third transect ran up the foot of a WNW-facing slope that rises to an elevation of about $800 \mathrm{~m}$ asl over a distance of $1.9 \mathrm{~km}$. Only the basal $160 \mathrm{~m}$ of this slope was surveyed. Surficial materials along the transect comprised angular rocks embedded in a matrix of coarse sediments, interpreted as till and colluvium. The first $110 \mathrm{~m}$ of the profile was cut by a network of shallow channels lined with rocks as at Transect 2, and with water levels $25-30 \mathrm{~cm}$ below the adjacent terrain. Between 110 and $160 \mathrm{~m}$, the slope became drier and slightly steeper. Vegetation was comprised of grasses and mosses in the lowest part of the profile with scattered willows. Cover decreased in the last section of the profile which was drier and had a higher concentration of surface rocks.

The tomogram for Transect 3 is the most complex of the three. In general, resistivities increase with depth, but there is considerable lateral variation in the near-surface layers (Figure $8 \mathrm{C}$ ). Values in the first half of the profile are as low as $1300 \Omega \mathrm{m}$ in the upper $3 \mathrm{~m}$ close to or in the channels, rising to $>13,000 \Omega \mathrm{m}$ at the base of the profile at $25 \mathrm{~m}$ depth. The near-surface to depth resistivity gradient is much reduced in the upper half of the profile where the slope gradient is about $5^{\circ}$ and surficial cover appears to become thinner. Near-surface resistivities range from 2150 to $9550 \Omega \mathrm{m}$, while deeper layers are in the $11,000 \Omega \mathrm{m}-15,000 \Omega \mathrm{m}$ range. Frost tables could be detected by probing at only 8 of 40 locations along the profile due to the high concentration of clasts, and all these were in the first half of the transect. Thaw depths ranged from 57 to $95 \mathrm{~cm}$, similar to two values $(75-90 \mathrm{~cm}$ ) estimated from instantaneous ground temperatures measured in the same parts of the profile. Probing depths attained in the final $40 \mathrm{~m}$ of the transect 

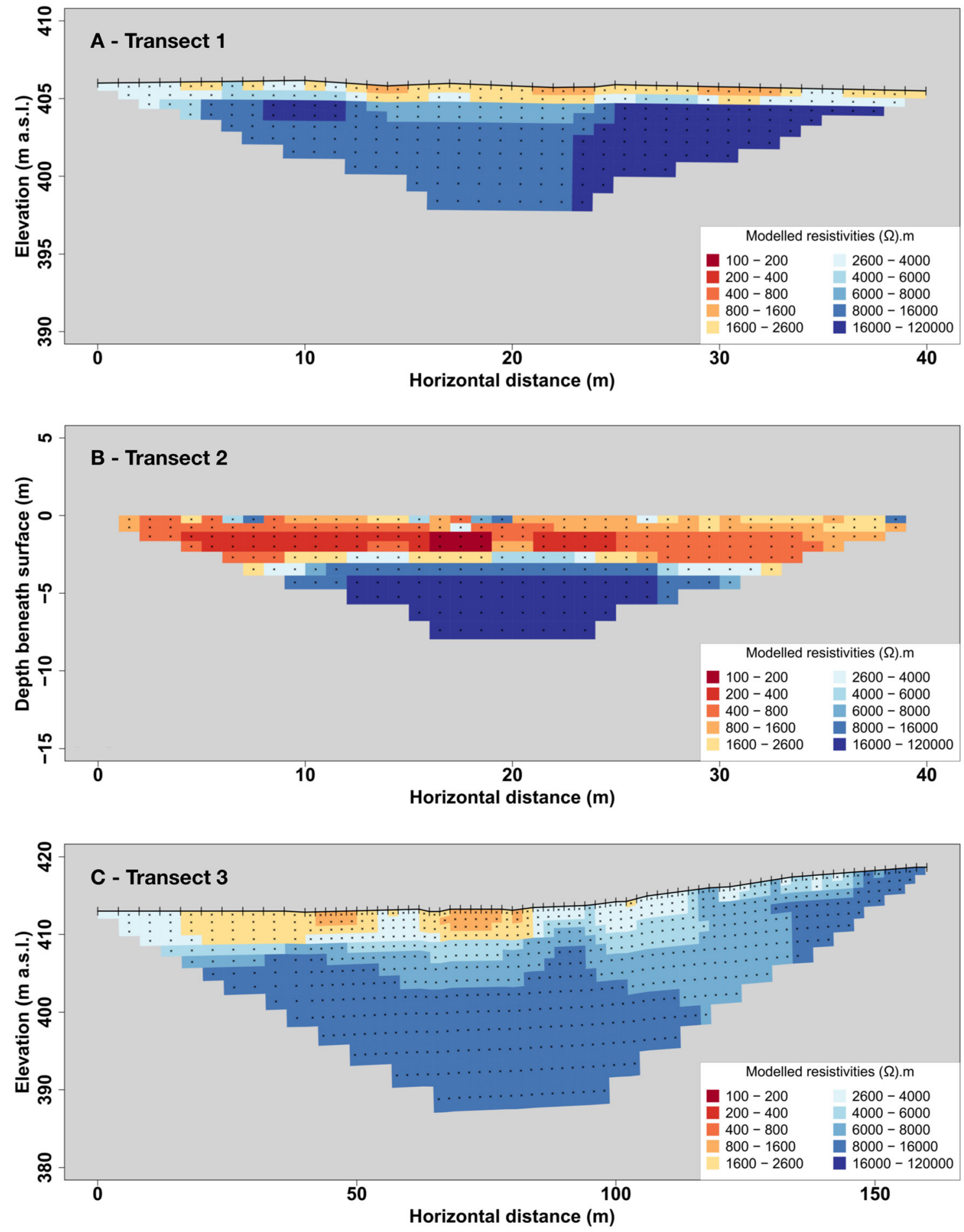

Figure 8. $X-Y-Z$ plots of modelled resistivities acquired with ERT at A Transect 1, B Transect 2 and $\mathbf{C}$ Transect 3 in late July 2017. Interpreted versions of the ERT profiles are presented in Supplementary Figure 4. Note elevation coordinates in B are not available. 
were only 10-40 cm which demonstrates high clast contents.

Combining all the data collected for this transect, it is concluded that permafrost is likely present throughout, but surficial sediments become thicker downslope which allows the wet surface thawed layer to be distinguished in the resistivity profile. The gradational increase in resistivities to a depth of $10 \mathrm{~m}$ in this part of the profile suggests changes in frozen ground conditions (possibly due to temperature or ice content change). Below $10 \mathrm{~m}$ depth, the high resistivities could be due to more frozen soil layers, or bedrock. In the upper part of the profile, drier conditions and from the geomorphological context, a possible bedrock contact approaching the surface, resulted in higher resistivities and less contrast with depth.

\section{Simulation of Permafrost Probability}

Simulated permafrost probabilities based on ground surface temperature data at the vegetation plots ranged from 9 to $100 \%$ with a mean probability of permafrost of $55 \%$ for the 14 logger sites (Figure 9). Nine of 14 sites had permafrost probabilities exceeding $25 \%$, and dry sites typically had a much higher permafrost probability and less variability (mean: 79\%; sd: 30\%) compared to wet sites (mean: $32 \%$; sd: $28 \%$ ). These data indicate the distribution of permafrost at Nakvak Brook is

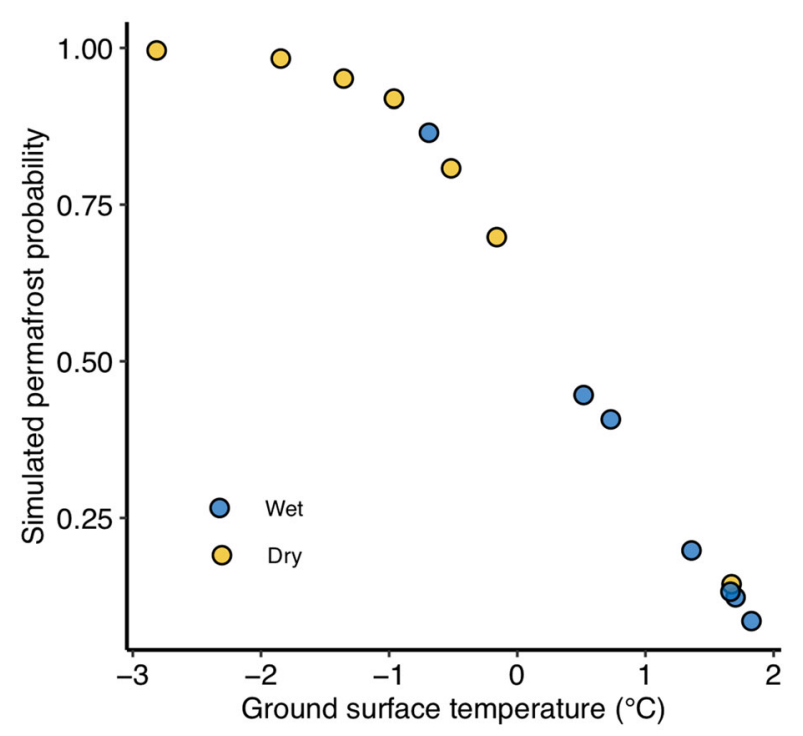

Figure 9. Simulated permafrost probability for 14 of 20 vegetation plots estimated from 1000 simulations using the temperature at the top of the permafrost model. Models are based on mean ground surface temperatures over the period 2011-2018. widespread but discontinuous, in agreement with our interpretations of the ERT data.

\section{Discussion}

Using a mixed-methods approach, we found evidence of rapid, ongoing changes in climate and vegetation conditions in the low Arctic Torngat Mountains of northern Labrador. We have attempted to move towards an integrated understanding of interactions between above-ground and subsurface conditions, which are complex and difficult to measure directly. Further environmental changes are expected in the coming decades, and our results highlight how and where future changes may manifest in the region.

\section{Relationships Between NDVI, Climate Change, and Shrub Growth}

Observed increases in NDVI at Nakvak Brook align with other reports of rapid vegetation change in the eastern Canadian Arctic and Subarctic (Fraser and others 2011; Tremblay and others 2012; Quirouette and Zorn 2015) and demonstrate that greening has continued since the publication of these earlier studies. Tundra greening is generally related to increased plant productivity or changes in species composition (Myers-Smith and others 2020); our dendrochronological analyses and point-frame surveys provide insight into the factors underlying the increase in NDVI at Nakvak Brook.

Recent shrubification is indicated by the records of ramet establishment and shrub growth. The ramet establishment dates show that stem initiation began in 1997 and peaked in 2006. Arctic shrubs have relatively long potential lifespans (decades to over a century; Myers-Smith and others 2015 and references therein); thus, the young ages of the ramets could indicate that limiting conditions were relaxed relatively recently. We did not quantitatively analyse the relationship between climate and establishment frequency; however, stem initiation tended to be higher during years with warmer July temperatures suggesting that a pulse in shrub establishment may have been triggered by warming in the mid-to-late 1990s. Shrub recruitment elsewhere has shown variable responses to climate. Myers-Smith and Hik (2017) found recruitment to be positively correlated to winter temperatures (willows; Yukon, Canada), whereas Frost and Epstein (2014) found tall shrub expansion to be more sensitive to precipitation (alder; northern Siberia). Büntgen and others (2015) found historical shrub recruitment to initially respond to increased 
temperatures but to decline in recent decades despite renewed warming (various species; East Greenland). Variability in recruitment responses to climate change may be caused by regional and species-level differences in climate limitations and the moderating influence of local factors (for example, herbivory; soil moisture; disturbance; Frost and others 2013; Lantz and others 2013). A comprehensive study of the relationships between climate and shrub recruitment would help confirm whether summer temperatures are a dominant control on shrub expansion in the study region.

Increases in NDVI at Nakvak Brook also appear to be driven by recent and rapid shrub growth. The lengths of shrub ramets increased exponentially at the site level, indicating an easing of limitations to primary growth over time. Stem lengths of Arctic shrubs have been shown to respond favourably to ambient warming and to experimental warming and fertilization treatments (Bret-Harte and others 2002). The analysis of our dwarf birch growth chronology also demonstrates a quantitative link between shrub growth, summer temperatures, and NDVI. Ropars and others (2015a) similarly found the radial growth of dwarf birch to be positively correlated to summer temperatures and NDVI in Nunavik, and suggested the greening trend detected in that region to be driven by dwarf birch growth.

The focus of our research was on climatic impacts; however, it is possible that reduced herbivore pressure from caribou in the Torngat Mountains contributed to the process of shrubification as the large decline in numbers between the 1980s and 2014 coincided with a period of warming. Research has shown that herbivory by Arctic ungulates can reduce but generally not reverse the process of tundra shrubification (Christie and others 2015). For instance, in Nunavik, Morrissette-Boileau and others (2018) found that herbivory did not counteract the influence of climate warming on shrub expansion, even during periods of very high caribou abundance. Experimental field studies and continued caribou monitoring are required to determine if vegetation in the Torngat Mountains is similarly resilient to the impacts of caribou browsing.

\section{Plot-Scale Vegetation Change}

Changes in vegetation detected in point-frame surveys were more subtle than the temporal trends observed in the shrub-ring records, and depended heavily on site context. Plot-level differences in vegetation size and abundance were mainly driven by the moisture status of the plots, reflecting the importance of microhabitat conditions in determining broader patterns of vegetation composition (Oberbauer and Dawson 1992). Previous research has found soil moisture to have a moderating effect on the sensitivity of tundra plant responses to temperature warming across multiple spatial scales (Elmendorf and others 2012a; Ackerman and others 2017; Bjorkman and others 2018), and we also found some indication of this tendency at Nakvak Brook.

Interactions between soil moisture and time resulted in a decline in moss abundance in 2015 in wet plots; mosses are sensitive to soil moisture and their tolerance to desiccation can be reduced by prolonged exposure to warm and dry conditions (Dorrepaal and others 2003). Our field observations of soil moisture suggest a drying trend among wet plots at Nakvak Brook, which combined with elevated temperatures, likely contributed to the decline in mosses. A surprising finding of the pointframe surveys was a slight but statistically significant increase in lichen abundance between years that was not related to plot moisture (although lichens were more abundant in dry plots overall). Vegetation surveys have frequently reported reduced lichen cover in response to warming temperatures (Cornelissen and others 2001; Walker and others 2006; Paradis and others 2016). Similar to our findings, however, Siegwart Collier (2020) observed lichen cover to increase from 2009 to 2016 in her vegetation plots exposed to ambient conditions in Nain and Torr Bay, Nunatsiavut. Lichen decline is typically attributed to increased shading by deciduous shrubs and plant litter, which we did not observe at Nakvak Brook (that is, deciduous shrubs were not significantly taller or abundant in 2015 than in 2010, and litter/dead plant material declined).

Altogether, the effect of site moisture class on vegetation cover and abundance was stronger than the effect of sampling year, which may be due to the lack of a warming trend over the 5 years between observations. The strength of warming has been shown to influence the likelihood of plants undergoing an increase in abundance or cover (Elmendorf and others 2012b). Locally scaled climate data showed summer temperatures to be higher in 2010, the first year of data collection, than in any year since 1979. Although remaining elevated above the long-term average, temperatures underwent a short-term decline from 2010 to 2015. 


\section{Connections Between Vegetation Change and Subsurface Characteristics}

Ground surface temperature data provide a link between atmospheric temperatures, plant growth, and the subsurface conditions of the study site. Plot-level comparisons of NVO and TSO between moisture classes show that wet plots, in which deciduous shrubs were taller, experienced higher cold season soil temperatures than dry plots. The ability of shrubs to trap snow and insulate the ground has been widely reported (Pomeroy and others 1997; Sturm and others 2005; Myers-Smith and Hik 2013; Roy-Léveillée and others 2014; Domine and others 2016), and we also found the insulating effect to be moderated by soil moisture, possibly through its influence on shrub size or soil freezing characteristics. Annual NVO values at Nakvak Brook varied by an order of magnitude $\left(0.8{ }^{\circ} \mathrm{C}-8.4{ }^{\circ} \mathrm{C}\right)$ and were comparable to other reported winter warming effects (Sturm and others 2001a, 2005; Myers-Smith and Hik 2013; Domine and others 2016; Paradis and others 2016). The more modest insulating effect in some plots at our study site could be due to the low overall size of the shrubs, since the insulating effect of snow has been shown to increase with plant height (Roy-Léveillée and others 2014). Alternatively, the greater maximum cooling effect in wet soils due to the release of latent heat during freezing may have contributed to differences in ground surface temperatures between plot types (Romanovsky and Osterkamp 2000). In either case, plot canopy height was positively correlated to average NVO values, and we expect that the insulating effect of shrub cover may increase in the future if shrubs continue to increase in size.

Analysis of in situ temperature and ERT data combined with field observations of permafrost (palsas) and frost-associated phenomena (sorted and polygonal features) suggest that permafrost is widespread at Nakvak Brook (Supplementary Figure 5), but generally at depths below the rooting zone of shrubs. However, the presence of nearsurface permafrost (for example, upper 3-4 m) is challenging to interpret within the study area. At Transect 1, inferred permafrost was ubiquitous along the ERT profile, whereas at Transect 2 it was inferred to be absent. At Transect 3, frozen ground in the near-surface layers was likely present along sections of the transect, while other sections were difficult to interpret or impacted by near-surface bedrock. Stream channels were areas of localized deeper thaw and permafrost was largely absent in the near-surface. Generally, coarser surficial materials and very wet surface conditions were associated with an inferred deeper active layer and warmer ground temperatures in the near-surface layers while finer surface materials were associated with a thinner active layer and moderate surface wetness.

Field observations of surface wetness changes during annual field visits to Transect 2 in particular suggest that subsurface hydrological changes may have occurred prior to enhanced shrub invasion. The contrast between frozen ground with a shallow active layer (Transect 1) and absent near-surface permafrost (Transect 2) makes it plausible that permafrost thaw could have modified subsurface hydrological conduits at the latter site over the period of observation. We hypothesize that the potential for ecological impacts of permafrost change at Nakvak Brook depends heavily on geomorphological context with moderately wet sites having finer materials being the most likely to have permafrost currently limiting vegetation growth and representing potential hot-spots for future change. In general, the permafrost simulations combined with the ERT data suggest that mid-elevations in the southern portions of the Torngat Mountains may be better classified as falling within the extensive discontinuous permafrost zone per Way and Lewkowicz (2016) as opposed to the continuous permafrost zone (for example, Permafrost Map of Canada).

\section{Implications of Change}

Over the past four decades, significant changes have occurred at Nakvak Brook with implications both for people as well as the broader environment. The changes we have documented may affect how Nunatsiavummiut and Nunavimmiut use the region for travel, hunting, and gathering plants. Shrubification in Torngat Mountains National Park will make it more difficult for Inuit to access travel routes by snowmobile, may alter the distribution of berry plants, and will change food availability for caribou and bear. In valley bottoms, where we observed significant greening, tall shrubs also provide cover for black bears and polar bears, increasing safety concerns. The study area is also located within one of Canada's National Parks and is intended to be representative of the southern limit of the Canadian Arctic Cordillera. Many protected areas in North America are expected to experience a shift in biome representation by the end of the century (Lemieux and Scott 2005; Holsinger and others 2019), and northern protected areas may become increasingly important refuges 
for species migrating northward (Berteaux and others 2018). Our results indicate that environmental change is already detectable at an extreme, mid-elevation research basin in Torngat Mountains National Park, an example of the disproportionate influence of climate change on protected areas (for example, Gonzalez and others 2018).

\section{Conclusions}

Applying an interdisciplinary lens and mixedmethods approach, this study provides a multivariable assessment of environmental change at the Nakvak Brook research basin located in the low shrub tundra ecotone in Torngat Mountains National Park, northern Labrador. Our findings confirm that vegetation greening is ongoing in the area and provide direct evidence that greening is driven by the influence of warming temperatures on shrub establishment and growth. Our data establish a link between vegetation cover and ground surface temperatures during the snow season with the expectation that future growth responses to warming may enhance this effect. At the plot scale, we found plant size and cover differences to be primarily driven by soil moisture regime, a characteristic that is tied both to atmospheric warming as well as subsurface conditions and that will be an important mediator of future responses to climate change. Near-surface permafrost was variable throughout the study area, and its importance for above-ground vegetation depends heavily on local geomorphological context. Continued research into connections above and below the soil surface and regional hydrological connectivity is warranted to evaluate the impacts of climate change on vegetation and permafrost conditions over the coming decades.

\section{ACKNOWLEDGEMENTS}

The authors would like to thank the Inuit of Nunatsiavut, Nunavik, and the Cooperative Management Board of Torngat Mountains National Park for their support of this project and acknowledge that the field research was conducted on their traditional lands. We thank our many bear guides, especially Boonie Merkuratsuk, Eli Merkuratsuk, Herman Merkuratsuk, John Merkuratsuk, and Maria Merkuratsuk, and Sarah Chan, Britt Cranston, Caitlin Lapalme, Julia Wheeler for assistance with fieldwork. Rodd Laing, Paul McCarney (both of Nunatsiavut Government), and Gary Baikie, Martin Lougheed, Jacko Merkuratsuk, Judy Rowell, and Angus Simpson (Parks Canada) for logisti- cal support. We thank John Jacobs for his early contributions to establishing the field site at Nakvak Brook. This research was funded by ArcticNet, the Canadian Foundation for Innovation, the Labrador Institute, Memorial University of Newfoundland, NSERC, the Nunatsiavut Government, Parks Canada, Queen's University, the Royal Canadian Geographical Society, University of Ottawa, and the W. Garfield Weston Foundation.

\section{DATA AVAILABILITY}

The data used in this research are available through the Polar Data Catalogue (https://doi.org/10.2196 $3 / 13196$ ) or by contacting the corresponding author.

\section{Compliance with ethical standards}

Conflict of interest The authors declare that they have no conflict of interest.

\section{OPEN ACCESS}

This article is licensed under a Creative Commons Attribution 4.0 International License, which permits use, sharing, adaptation, distribution and reproduction in any medium or format, as long as you give appropriate credit to the original author(s) and the source, provide a link to the Creative Commons licence, and indicate if changes were made. The images or other third party material in this article are included in the article's Creative Commons licence, unless indicated otherwise in a credit line to the material. If material is not included in the article's Creative Commons licence and your intended use is not permitted by statutory regulation or exceeds the permitted use, you will need to obtain permission directly from the copyright holder. To view a copy of this licence, visit $h$ ttp://creativecommons.org/licenses/by/4.0/.

\section{REFERENCES}

Ackerman D, Griffin D, Hobbie SE, Finlay JC. 2017. Arctic shrub growth trajectories differ across soil moisture levels. Global Change Biology 23:4294-4302.

Andruko R, Danby R, Grogan P. 2020. Recent Growth and Expansion of Birch Shrubs Across a Low Arctic Landscape in Continental Canada: Are These Responses More a Consequence of the Severely Declining Caribou Herd than of Climate Warming? Ecosystems.

Banfield CE, Jacobs JD. 1998. Regional patterns of temperature and precipitation for Newfoundland and Labrador during the past century. The Canadian Geographer 42:354-364. 
Barrand NE, Way RG, Bell T, Sharp MJ. 2017. Recent changes in area and thickness of Torngat Mountain glaciers (northern Labrador, Canada). The Cryosphere 11:157-168.

Barrette C, Brown R, Way R, Mailhot A, Diaconescu EP, Grenier P, Chaumont D, Dumont D, Sévigny C, Howell S, Senneville S. 2020. Chapter 2: Nunavik and Nunatsiavut regional climate information update. In Ropars P, Allard M, Lemay M (eds.), Nunavik and Nunatsiavut: From science to policy, an integrated regional impact study (IRIS) of climate change and modernization, second iteration. Québec, Canada.

Bates D, Maechler M, Bolker B, Walker S. 2015. Fitting Linear Mixed-Effects Models Using lme4. Journal of Statistical Software $67: 1-48$.

Berteaux D, Ricard M, St-Laurent MH, Casajus N, Perie C, Beauregard F, de Blois S. 2018. Northern protected areas will become important refuges for biodiversity tracking suitable climates. Scientific Reports 8:4623.

Bjorkman AD, Myers-Smith IH, Elmendorf SC, Normand S, Ruger $\mathrm{N}$, Beck PSA, Blach-Overgaard A, Blok D, Cornelissen JHC, Forbes BC, Georges D, Goetz SJ, Guay KC, Henry GHR, HilleRisLambers J, Hollister RD, Karger DN, Kattge J, Manning P, Prevey JS, Rixen C, Schaepman-Strub G, Thomas HJD, Vellend M, Wilmking M, Wipf S, Carbognani M, Hermanutz L, Levesque E, Molau U, Petraglia A, Soudzilovskaia NA, Spasojevic MJ, Tomaselli M, Vowles T, Alatalo JM, Alexander HD, Anadon-Rosell A, Angers-Blondin S, Beest MT, Berner L, Bjork RG, Buchwal A, Buras A, Christie K, Cooper EJ, Dullinger S, Elberling B, Eskelinen A, Frei ER, Grau O, Grogan P, Hallinger M, Harper KA, Heijmans M, Hudson J, Hulber K, IturrateGarcia M, Iversen CM, Jaroszynska F, Johnstone JF, Jorgensen RH, Kaarlejarvi E, Klady R, Kuleza S, Kulonen A, Lamarque LJ, Lantz T, Little CJ, Speed JDM, Michelsen A, Milbau A, NabeNielsen J, Nielsen SS, Ninot JM, Oberbauer SF, Olofsson J, Onipchenko VG, Rumpf SB, Semenchuk P, Shetti R, Collier LS, Street LE, Suding KN, Tape KD, Trant A, Treier UA, Tremblay JP, Tremblay M, Venn S, Weijers S, Zamin T, Boulanger-Lapointe N, Gould WA, Hik DS, Hofgaard A, Jonsdottir IS, Jorgenson J, Klein J, Magnusson B, Tweedie C, Wookey PA, Bahn $\mathrm{M}$, Blonder B, van Bodegom PM, Bond-Lamberty B, Campetella G, Cerabolini BEL, Chapin FS 3rd, Cornwell WK, Craine J, Dainese M, de Vries FT, Diaz S, Enquist BJ, Green W, Milla R, Niinemets U, Onoda Y, Ordonez JC, Ozinga WA, Penuelas J, Poorter H, Poschlod P, Reich PB, Sandel B, Schamp B, Sheremetev S, Weiher E. 2018. Plant functional trait change across a warming tundra biome. Nature 562:57-62.

Blok D, Heijmans MMPD, Schaepman-Strub G, Kononov AV, Maximov TC, Berendse F. 2010. Shrub expansion may reduce summer permafrost thaw in Siberian tundra. Global Change Biology 16:1296-1305.

Boelman NT, Gough L, McLaren JR, Greaves H. 2011. Does NDVI reflect variation in the structural attributes associated with increasing shrub dominance in arctic tundra? Environmental Research Letters 6:035501.

Bret-Harte MS, Shaver GR, Chapin FS III. 2002. Primary and secondary stem growth in arctic shrubs: implications for community response to environmental change. Journal of Ecology 90:251-267.

Büntgen U, Hellmann L, Tegel W, Normand S, Myers-Smith I, Kirdyanov AV, Nievergelt D, Schweingruber FH. 2015. Temperature-induced recruitment pulses of Arctic dwarf shrub communities. Journal of Ecology 103:489-501.

Chagnon C, Boudreau S. 2019. Shrub canopy induces a decline in lichen abundance and diversity in Nunavik (Québec, Canada). Arctic, Antarctic, and Alpine Research 51:521-532.
Chapin FS III, Shaver GR, Giblin AE, Nadelhoffer KJ, Laundre JA. 1995. Responses of Arctic Tundra to Experimental and Observed Changes in Climate. Ecology 76:694-711.

Chapin FS III, Sturm M, Serreze MC, McFadden JP, Key JR, Lloyd AH, McGuire AD, Rupp TS, Lynch AH, Schimel JP, Beringer J, Chapman WL, Epstein HE, Euskirchen ES, Hinzman LD, Jia G, Ping C-L, Tape KD, Thompson CDC, Walker DA, Welker JM. 2005. Role of Land-Surface Changes in Arctic Summer Warming. Science 310:657-660.

Christie KS, Bryant JP, Gough L, Ravolainen VT, Ruess RW, Tape KD. 2015. The Role of Vertebrate Herbivores in Regulating Shrub Expansion in the Arctic: A Synthesis. BioScience 65:1123-1133.

Cook ER, Briffa KR, Shiyatov SG, Mazepa VS. 1990. Tree-ring Standardization and Growth-Trend Estimation. Cook ER, Kairiukstis LA editors. Methods of Dendrochronology: Applications in the Environmental Sciences: SpringerScience+Business Media, B.V., p 104-123.

Cornelissen JHC, Callaghan TV, Alatalo JM, Michelsen A, Graglia E, Hartley AE, Hik DS, Hobbie SE, Press MC, Robinson CH, Henry GHR, Shaver GR, Phoenix GK, Gwynn Jones D, Jonasson S, Chapin FS, Molau U, Neill C, Lee JA, Melillo JM, Sveinbjornsson B, Aerts R. 2001. Global change and arctic ecosystems: is lichen decline a function of increases in vascular plant biomass? Journal of Ecology 89:984-994.

COSEWIC. 2017. COSEWIC assessment and status report on the Caribou Rangifer tarandus, Eastern Migratory population and Torngat Mountains population, in Canada. Ottawa: xvii +68 .

Couturier S, Dale A, Mitchell Foley J, Snook J, Wood A. 2015. First scientific data on herd size and population dynamics of the Torngat Mountains caribou herd. Torngat Wildlife, Plants and Fisheries Secretariat. Ser. 2015/43+9 p.

Couturier S, Dale A, Wood B, Snook J. 2018. Results of a spring 2017 aerial survey of the Torngat Mountains Caribou Herd. Torngat Wildlife, Plants and Fisheries Secretariat. Ser. 2018/40 $+10 \mathrm{p}$.

Cuerrier A, Brunet ND, Gérin-Lajoie J, Downing A, Lévesque E. 2015. The Study of Inuit Knowledge of Climate Change in Nunavik, Quebec: A Mixed Methods Approach. Human Ecology 43:379-394.

Cunsolo Willox A, Harper SL, Ford JD, Landman K, Houle K, Edge VL, Rigolet Inuit Community G. 2012. "From this place and of this place:" climate change, sense of place, and health in Nunatsiavut, Canada. Social Science \& Medicine 75:538547.

Domine F, Barrere M, Morin S. 2016. The growth of shrubs on high Arctic tundra at Bylot Island: impact on snow physical properties and permafrost thermal regime. Biogeosciences 13:6471-6486.

Dorrepaal E, Aerts R, Cornelissen JHC, Callaghan TV, van Logtestijn RSP. 2003. Summer warming and increased winter snow cover affect Sphagnum fuscum growth, structure and production in a sub-arctic bog. Global Change Biology 10:93104

Downing A, Cuerrier A. 2011. A synthesis of the impacts of climate change on the First Nations and Inuit of Canada. Indian Journal of Traditional Knowledge 10:57-70.

Dyke AS. 2004. An outline of North American Deglaciation with emphasis on central and northern Canada. Developments in Quaternary Sciences: Elsevier, p 373-424.

Elmendorf SC, Henry GH, Hollister RD, Bjork RG, Bjorkman AD, Callaghan TV, Collier LS, Cooper EJ, Cornelissen JH, Day TA, Fosaa AM, Gould WA, Gretarsdottir J, Harte J, Hermanutz L, 
Hik DS, Hofgaard A, Jarrad F, Jonsdottir IS, Keuper F, Klanderud K, Klein JA, Koh S, Kudo G, Lang SI, Loewen V, May JL, Mercado J, Michelsen A, Molau U, Myers-Smith IH, Oberbauer SF, Pieper S, Post E, Rixen C, Robinson CH, Schmidt NM, Shaver GR, Stenstrom A, Tolvanen A, Totland O, Troxler T, Wahren CH, Webber PJ, Welker JM, Wookey PA. 2012a. Global assessment of experimental climate warming on tundra vegetation: heterogeneity over space and time. Ecology Letters 15:164-175.

Elmendorf SC, Henry GHR, Hollister RD, Björk RG, BoulangerLapointe N, Cooper EJ, Cornelissen JHC, Day TA, Dorrepaal E, Elumeeva TG, Gill M, Gould WA, Harte J, Hik DS, Hofgaard A, Johnson DR, Johnstone JF, Jónsdóttir IS, Jorgenson JC, Klanderud K, Klein JA, Koh S, Kudo G, Lara M, Lévesque E, Magnússon B, May JL, Mercado-Díaz JA, Michelsen A, Molau U, Myers-Smith IH, Oberbauer SF, Onipchenko VG, Rixen C, Martin Schmidt N, Shaver GR, Spasojevic MJ, Pórhallsdóttir PE, Tolvanen A, Troxler T, Tweedie CE, Villareal S, Wahren CH, Walker X, Webber PJ, Welker JM, Wipf S. 2012b. Plot-scale evidence of tundra vegetation change and links to recent summer warming. Nature Climate Change 2:453-457.

Finnis J, Bell T. 2015. An analysis of recent observed climate trends and variability in Labrador. The Canadian Geographer / Le Géographe canadien 59:151-166.

Fraser RH, Olthof I, Carrière M, Deschamps A, Pouliot D. 2011. Detecting long-term changes to vegetation in northern Canada using the Landsat satellite image archive. Environmental Research Letters 6.

Frost GV, Epstein HE. 2014. Tall shrub and tree expansion in Siberian tundra ecotones since the 1960s. Global Change Biology 20:1264-1277.

Frost GV, Epstein HE, Walker DA, Matyshak G, Ermokhina K. 2013. Patterned-ground facilitates shrub expansion in Low Arctic tundra. Environmental Research Letters 8:015035.

Gonzalez P, Wang F, Notaro M, Vimont DJ, Williams JW. 2018. Disproportionate magnitude of climate change in United States national parks. Environmental Research Letters 13:104001.

Gorelick N, Hancher M, Dixon M, Ilyushchenko S, Thau D, Moore R. 2017. Google Earth Engine: Planetary-scale geospatial analysis for everyone. Remote Sensing of Environment 202:18-27.

Hauck C. 2013. New Concepts in Geophysical Surveying and Data Interpretation for Permafrost Terrain. Permafrost and Periglacial Processes 24:131-137.

Hauck C, Vonder Mühll D, Maurer H. 2003. Using DC resistivity tomography to detect and characterize mountain permafrost. Geophysical Prospecting 51:273-284.

Heginbottom JA, Dubreuil MA, Harker PA. 1995. National Atlas of Canada. Ottawa, Ontario: Natural Resources Canada.

Hersbach H, Bell B, Berrisford P, Hirahara S, Horányi A, MuñozSabater J, Nicolas J, Peubey C, Radu R, Schepers D, Simmons A, Soci C, Abdalla S, Abellan X, Balsamo G, Bechtold P, Biavati $G$, Bidlot J, Bonavita M, Chiara G, Dahlgren P, Dee D, Diamantakis M, Dragani R, Flemming J, Forbes R, Fuentes M, Geer A, Haimberger L, Healy S, Hogan RJ, Hólm E, Janisková M, Keeley S, Laloyaux P, Lopez P, Lupu C, Radnoti G, Rosnay P, Rozum I, Vamborg F, Villaume S, Thépaut JN. 2020. The ERA5 global reanalysis. Quarterly Journal of the Royal Meteorological Society 146:1999-2049.

Holloway JE, Lewkowicz AG. 2020. Half a century of discontinuous permafrost persistence and degradation in western Canada. Permafrost and Periglacial Processes 31:85-96.
Holsinger L, Parks SA, Parisien MA, Miller C, Batllori E, Moritz MA. 2019. Climate change likely to reshape vegetation in North America's largest protected areas. Conservation Science and Practice 1:e50.

Jacobs JD, Chan S, Sutton E. 2014. Climatology of the ForestTundra Ecotone at a Maritime Subarctic-Alpine Site, Mealy Mountains, Labrador. Arctic 67:28-42.

Johansson M, Callaghan TV, Bosiö J, Åkerman HJ, JackowiczKorczynski M, Christensen TR. 2013. Rapid responses of permafrost and vegetation to experimentally increased snow cover in sub-arctic Sweden. Environmental Research Letters 8:035025.

Joly K, Jandt RR, Klein DR. 2009. Decrease of lichens in Arctic ecosystems: the role of wildfire, caribou, reindeer, competition and climate in north-western Alaska. Polar Research 28:433-442.

Ju J, Masek JG. 2016. The vegetation greenness trend in Canada and US Alaska from 1984-2012 Landsat data. Remote Sensing of Environment 176:1-16.

Lantz TC, Kokelj SV, Gergel SE, Henry GHR. 2009. Relative impacts of disturbance and temperature: persistent changes in microenvironment and vegetation in retrogressive thaw slumps. Global Change Biology 15:1664-1675.

Lantz TC, Marsh P, Kokelj SV. 2013. Recent Shrub Proliferation in the Mackenzie Delta Uplands and Microclimatic Implications. Ecosystems 16:47-59.

Lawrence DM, Swenson SC. 2011. Permafrost response to increasing Arctic shrub abundance depends on the relative influence of shrubs on local soil cooling versus large-scale climate warming. Environmental Research Letters 6.

Lemieux CJ, Scott DJ. 2005. Climate change, biodiversity conservation and protected area planning in Canada. The Canadian Geographer 49:384-399.

Lewkowicz AG, Etzelmüller B, Smith SL. 2011. Characteristics of Discontinuous Permafrost based on Ground Temperature Measurements and Electrical Resistivity Tomography, Southern Yukon, Canada. Permafrost and Periglacial Processes $22: 320-342$.

Loke MH, Acworth I, Dahlin T. 2003. A comparison of smooth and blocky inversion methods in 2D electrical imaging surveys. Exploration Geophysics 34:182-187.

Loke MH, Barker RD. 1996. Rapid least-squares inversion of apparent resistivity pseudosections by a quasi-Newton method. Geophysical Prospecting 44:131-152.

Loranty MM, Abbott BW, Blok D, Douglas TA, Epstein HE, Forbes BC, Jones BM, Kholodov AL, Kropp H, Malhotra A, Mamet SD, Myers-Smith IH, Natali SM, O'Donnell JA, Donnell JA, Phoenix GK, Rocha AV, Sonnentag O, Tape KD, Walker DA. 2018. Reviews and syntheses: Changing ecosystem influences on soil thermal regimes in northern high-latitude permafrost regions. Biogeosciences 15:5287-5313.

Loranty MM, Goetz SJ, Beck PSA. 2011. Tundra vegetation effects on pan-Arctic albedo. Environmental Research Letters 6:024014.

MacDougall AH, Knutti R. 2016. Projecting the release of carbon from permafrost soils using a perturbed parameter ensemble modelling approach. Biogeosciences 13:2123-2136.

McManus KM, Morton DC, Masek JG, Wang D, Sexton JO, Nagol JR, Ropars P, Boudreau S. 2012. Satellite-based evidence for shrub and graminoid tundra expansion in northern Quebec from 1986 to 2010. Global Change Biology 18:23132323. 
Mizel JD, Schmidt JH, Mcintyre CL, Roland CA. 2016. Rapidly shifting elevational distributions of passerine species parallel vegetation change in the subarctic. Ecosphere 7:e01264.

Morrissette-Boileau C, Boudreau S, Tremblay J-P, Côté SD. 2018. Revisiting the role of migratory caribou in the control of shrub expansion in northern Nunavik (Québec, Canada). Polar Biology 41:1845-1853.

Myers-Smith IH, Forbes BC, Wilmking M, Hallinger M, Lantz T, Blok D, Tape KD, Macias-Fauria M, Sass-Klaassen U, Lévesque E, Boudreau S, Ropars P, Hermanutz L, Trant A, Collier LS, Weijers S, Rozema J, Rayback SA, Schmidt NM, SchaepmanStrub G, Wipf S, Rixen C, Ménard CB, Venn S, Goetz S, Andreu-Hayles L, Elmendorf S, Ravolainen V, Welker J, Grogan P, Epstein HE, Hik DS. 2011. Shrub expansion in tundra ecosystems: dynamics, impacts and research priorities. Environmental Research Letters 6:045509.

Myers-Smith IH, Hallinger M, Blok D, Sass-Klaassen U, Rayback SA, Weijers S, Trant AJ, Tape KD, Naito AT, Wipf S, Rixen C, Dawes MA, Wheeler AJ, Buchwal A, Baittinger C, MaciasFauria M, Forbes BC, Lévesque E, Boulanger-Lapointe N, Beil I, Ravolainen V, Wilmking M. 2015. Methods for measuring arctic and alpine shrub growth: A review. Earth-Science Reviews 140:1-13.

Myers-Smith IH, Hik DS. 2013. Shrub canopies influence soil temperatures but not nutrient dynamics: An experimental test of tundra snow-shrub interactions. Ecology and Evolution 3:3683-3700.

Myers-Smith IH, Hik DS. 2017. Climate warming as a driver of tundra shrubline advance. Journal of Ecology 106:547-560.

Myers-Smith IH, Kerby JT, Phoenix GK, Bjerke JW, Epstein HE, Assmann JJ, John C, Andreu-Hayles L, Angers-Blondin S, Beck PSA, Berner LT, Bhatt US, Bjorkman AD, Blok D, Bryn A, Christiansen CT, Cornelissen JHC, Cunliffe AM, Elmendorf SC, Forbes BC, Goetz SJ, Hollister RD, de Jong R, Loranty MM, Macias-Fauria M, Maseyk K, Normand S, Olofsson J, Parker TC, Parmentier F-JW, Post E, Schaepman-Strub G, Stordal F, Sullivan PF, Thomas HJD, Tømmervik H, Treharne R, Tweedie CE, Walker DA, Wilmking M, Wipf S. 2020. Complexity revealed in the greening of the Arctic. Nature Climate Change 10:106-117.

Nychka D, Furrer R, Paige J, Sain S. 2017. fields: Tools for spatial data. Boulder, CO, USA.

Oberbauer SF, Dawson TE. 1992. Water relations of arctic vascular plants. Arctic ecosystems in a changing climate: An ecophysiological perspective, p 259-279.

Obu J, Westermann S, Bartsch A, Berdnikov N, Christiansen HH, Dashtseren A, Delaloye R, Elberling B, Etzelmüller B, Kholodov A, Khomutov A, Kääb A, Leibman MO, Lewkowicz AG, Panda SK, Romanovsky V, Way RG, Westergaard-Nielsen A, Wu T, Yamkhin J, Zou D. 2019. Northern Hemisphere permafrost map based on TTOP modelling for 2000-2016 at 1 km2 scale. Earth-Science Reviews 193:299-316.

Osterkamp TE, Jorgenson MT, Schuur EAG, Shur YL, Kanevskiy MZ, Vogel JG, Tumskoy VE. 2009. Physical and ecological changes associated with warming permafrost and thermokarst in Interior Alaska. Permafrost and Periglacial Processes 20:235-256.

Paradis M, Lévesque E, Boudreau S. 2016. Greater effect of increasing shrub height on winter versus summer soil temperature. Environmental Research Letters 11.

Parks Canada. 2008. State of the park report, Torngat Mountains National Park of Canada. Unpublished report. Rocky Harbour, Newfoundland and Labrador, Canada: Parks Canada.
Pearson RG, Phillips SJ, Loranty MM, Beck PSA, Damoulas T, Knight SJ, Goetz SJ. 2013. Shifts in Arctic vegetation and associated feedbacks under climate change. Nature Climate Change 3:673-677.

Pironkova Z, Whaley R, Lan K. 2018. Time series analysis of Landsat NDVI composites with Google Earth Engine and R: User guide. p 18.

Pomeroy JW, Marsh P, Gray DM. 1997. Application of a disturbed blowing snow model to the Arctic. Hydrological Processes 11:1451-1464.

Ponomarenko S, McLennan D. 2010. Delineation and Description of Bioclimatic Zones Torngat Mountains National Park Reserve, Canadian Arctic. International Association of Vegetation Science. Ensenada, Mexico.

Post E, Forchhammer MC, Bret-Harte MS, Callaghan TV, Christensen TR, Elberling B, Fox AD, Gilg O, Hik DS, Høye TT, Ims RA, Jeppesen E, Klein DR, Madsen J, McGuire AD, Rysgaard S, Schindler DE, Stirling I, Tamstorf MP, Tyler NJC, van der Wal R, Wlker J, Wookey PA, Schmidt NM, Astrup P. 2009. Ecological Dynamics Across the Arctic Associated with Recent Climate Change. Science 325:1355-1358.

Provencher-Nolet L, Bernier M, Lévesque E. 2014. Short term change detection in tundra vegetation near Umiujaq, subarctic Quebec, Canada. IEEE Geoscience and Remote Sensing Symposium: IEEE, p 4668-4670.

Quirouette J, Zorn P. 2015. Subtle Vegetation Change - Torngat Mountains. Gatineau, QC, Canada: Parks Canada.

R Core Team. 2020. R: A Language and Environment for Statistical Computing. Vienna, Austria: R Foundation for Statistical Computing.

Rapinski M, Payette F, Sonnentag O, Herrmann TM, Royer MJS, Cuerrier A, Siegwart Collier L, Hermanutz L, Guanish G, Kawawachikamach Eo, Kangiqsualujjuaq Eo, Nain Eo. 2018. Listening to Inuit and Naskapi peoples in the eastern Canadian Subarctic: a quantitative comparison of local observations with gridded climate data. Regional Environmental Change 18: 189-203.

Raynolds MK, Walker DA, Epstein HE, Pinzon JE, Tucker CJ. 2012. A new estimate of tundra-biome phytomass from transArctic field data and AVHRR NDVI. Remote Sensing Letters 3:403-411.

Riley JL, Notzl L, Greene R. 2013. Labrador Nature Atlas: Vol II, Ecozones, Ecoregions and Ecodistricts. Toronto, Ontario: Nature Conservancy of Canada, p 128.

Riseborough DW. 2004. Exploring the Parameters of a Simple Model of the Permafrost - Climate Relationship. Department of Geography and Environmental Studies. Ottawa, ON: Carelton University, p 346.

Romanovsky VE, Osterkamp TE. 2000. Effects of Unfrozen Water on Heat and Mass Transport Processes in the Active Layer and Permafrost. Permafrost and Periglacial Processes 11:219-239.

Ropars P, Lévesque E, Boudreau S. 2015a. How do climate and topography influence the greening of the forest-tundra ecotone in northern Québec? A dendrochronological analysis of Betula glandulosa. Journal of Ecology 103:679-690.

Ropars P, Lévesque E, Boudreau S. 2015b. Shrub densification heterogeneity in subarctic regions: the relative influence of historical and topographic variables. Ecoscience 22:83-95.

Roser LG, Ferreyra LI, Saidman BO, Vilardi JC. 2017. EcoGenetics: An R package for the management and exploratory 
analysis of spatial data in landscape genetics. Molecular Ecology Resources 17:e241-e250.

Roy-Léveillée P, Burn CR, McDonald ID. 2014. Vegetation-Permafrost Relations within the Forest-Tundra Ecotone near Old Crow, Northern Yukon, Canada. Permafrost and Periglacial Processes 25:127-135.

Sarrazin D, Allard M. 2020. Données des stations climatiques de la région de Kangiqsualujjuaq au Nunavik, Québec, Canada, v. 1.4 (1988-2019). Nordicana D14 doi: https://doi.org/10.58 85/45264SL-AF7FDA53F9E44927.

Schmelzer I, Lewis KP, Jacobs JD, McCarthy SC. 2020. Boreal caribou survival in a warming climate, Labrador, Canada 1996-2014. Global Ecology and Conservation 23:e01038.

Siegwart Collier L. 2020. Climate change impacts on berry shrub performance in treeline and tundra ecosystems. Department of Biology. St. Johns, NL: Memorial University of Newfoundland, p 249.

Smith MW, Riseborough DW. 1996. Permafrost Monitoring and Detection of Climate Change. Permafrost and Periglacial Processes 7:301-309.

Sturm M. 2005. Changing snow and shrub conditions affect albedo with global implications. Journal of Geophysical Research 110 .

Sturm M, McFadden JP, Liston GE, Chapin FS III, Racine CH, Holmgren J. 2001a. Snow-Shrub Interactions in Arctic Tundra: A Hypothesis with Climatic Implications. Journal of Climate 14:336-344.

Sturm M, Racine C, Tape K. 200 lb. Increasing shrub abundance in the Arctic. Natural Areas Journal 41 1:546-547.

Sturm M, Schimel J, Michaelson G, Welker JM, Oberbauer SF, Liston GE, Fahnestock J, Romanovsky V. 2005. Winter Biological Processes Could Help Convert Arctic Tundra to Shrubland. BioScience 55:17-26.

Tape KEN, Sturm M, Racine C. 2006. The evidence for shrub expansion in Northern Alaska and the Pan-Arctic. Global Change Biology 12:686-702.

Tremblay B, Lévesque E, Boudreau S. 2012. Recent expansion of erect shrubs in the Low Arctic: evidence from Eastern Nunavik. Environmental Research Letters 7:035501.

Turetsky MR, Abbott BW, Jones MC, Anthony KW, Olefeldt D, Schuur EAG, Grosse G, Kuhry P, Hugelius G, Koven C, Lawrence DM, Gibson C, Sannel ABK, McGuire AD. 2020. Carbon release through abrupt permafrost thaw. Nature Geoscience 13:138-143.

Turner J, Overland JE, Walsh JE. 2007. An Arctic and antarctic perspective on recent climate change. International Journal of Climatology 27:277-293.

Walker MD, Wahren CH, Hollister RD, Henry GH, Ahlquist LE, Alatalo JM, Bret-Harte MS, Calef MP, Callaghan TV, Carroll
AB, Epstein HE, Jonsdottir IS, Klein JA, Magnusson B, Molau U, Oberbauer SF, Rewa SP, Robinson CH, Shaver GR, Suding KN, Thompson CC, Tolvanen A, Totland O, Turner PL, Tweedie CE, Webber PJ, Wookey PA. 2006. Plant community responses to experimental warming across the tundra biome. Proceedings of the National Academy of Sciences 103:13421346.

Way RG, Bell T, Barrand NE. 2015. Glacier change from the early Little Ice Age to 2005 in the Torngat Mountains, northern Labrador, Canada. Geomorphology 246:558-569.

Way RG, Bonnaventure PP. 2015. Testing a reanalysis-based infilling method for areas with sparse discontinuous air temperature data in northeastern Canada. Atmospheric Science Letters 16:398-407.

Way RG, Lewkowicz AG. 2015. Investigations of discontinuous permafrost in coastal Labrador with DC electrical resistivity tomography. Proceedings of GéoQuebec: 68th Canadian Geotechnical Conference and 7th Canadian Permafrost Conference. Quebec City, Canada.

Way RG, Lewkowicz AG. 2016. Modelling the spatial distribution of permafrost in Labrador-Ungava using the temperature at the top of permafrost. Canadian Journal of Earth Sciences 53:1010-1028.

Way RG, Lewkowicz AG. 2018. Environmental controls on ground temperature and permafrost in Labrador, northeast Canada. Permafrost and Periglacial Processes 29:73-85.

Way RG, Lewkowicz AG, Bonnaventure PP. 2017. Development of moderate-resolution gridded monthly air temperature and degree-day maps for the Labrador-Ungava region of northern Canada. International Journal of Climatology 37:493-508.

Way RG, Lewkowicz AG, Zhang Y. 2018. Characteristics and fate of isolated permafrost patches in coastal Labrador, Canada. The Cryosphere 12:2667-2688.

Way RG, Viau AE. 2015. Natural and forced air temperature variability in the Labrador region of Canada during the past century. Theoretical and Applied Climatology 121:413-424.

Weintraub MN, Schimel JP. 2005. Nitrogen Cycling and the Spread of Shrubs Control Changes in the Carbon Balance of Arctic Tundra Ecosystems. BioScience 55:408-415.

Whitaker D. 2017. Expanded Range Limits of Boreal Birds in the Torngat Mountains of Northern Labrador. The Canadian Field-Naturalist 131:55-62.

Zamin TJ, Grogan P. 2012. Birch shrub growth in the low Arctic: the relative importance of experimental warming, enhanced nutrient availability, snow depth and caribou exclusion. Environmental Research Letters 7:034027.

Zhang T. 2005. Influence of the seasonal snow cover on the ground thermal regime: An overview. Reviews of Geophysics 43: RG4002. 